$1-1-1934$

\title{
Aiding West Virginia Agriculture Through Research : Report of the West Virginia Agricultural Experiment Station for the Biennium Ending June 30, 1934.
}

F. D. Fromme

Follow this and additional works at: https://researchrepository.wvu.edu/ wv_agricultural_and_forestry_experiment_station_bulletins

\section{Digital Commons Citation}

Fromme, F. D., "Aiding West Virginia Agriculture Through Research : Report of the West Virginia Agricultural Experiment Station for the Biennium Ending June 30, 1934." (1934). West Virginia Agricultural and Forestry Experiment Station Bulletins. 263.

https://researchrepository.wvu.edu/wv_agricultural_and_forestry_experiment_station_bulletins/264 @ WVU. It has been accepted for inclusion in West Virginia Agricultural and Forestry Experiment Station Bulletins by an authorized administrator of The Research Repository @ WVU. For more information, please contact ian.harmon@mail.wvu.edu. 


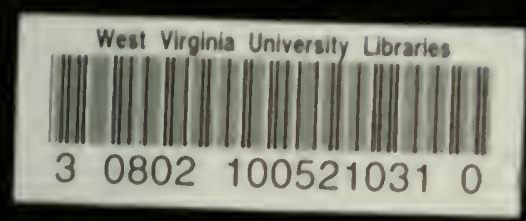


Digitized by the Internet Archive in 2010 with funding from

Lyrasis Members and Sloan Foundation 


\section{Aiding West Virginia Agriculture Through Research}

Report of the West Virginia Agricultural

Experiment Station for the Biennium

Ending June 30, 1934 
The period of economic distress of the past biennium has brought to the front as never before the value of accumulated reliable information pertaining to agriculture. The supreme test of values comes in periods of depression rather than in periods of prosperity. As the margin between profit and loss becomes narrower and narrower it becomes more and more necessary that practices be based on sound principles.

Most of the facts and principles on which modern agriculture is based have been accumulated during the past halfcentury throngh the work of the state agricultural experiment stations and the United States Department of Agriculture. Within this period revolutionary changes in farm practice, resulting in fundamental social and economic adjustments, have taken place. Many of the hazards of production have been eliminated or reduced, superior crop plants and farm animals have been evolved, the decline in fertility of the soil has been arrested, and the productive labor of the farmer has been increased many-fold.

This fund of scientific linowledge which has accumulated. during the past half-century of experiment and research has served not only to lessen the intensity of the depression and to alleviate the effects of unfavorable weather but has served also as a basis for the program of reconstruction which aims to build a more stable and profitable system of agriculture for the future. The national programs of land planning, erosion control, agricultural adjustment, and miral rehabilitation have not only drawn heavily on accumulated reserves of information; they have also taxed the facilities of research agencies for a host of additional facts.

The need for the continuance and expansion of such agencies as are capable of obtaining essential facts and of giving adequate interpretation to them is clearly shou'n. Sound adjustments for the present and sound programs for the future cannot be formulated without the widest possible inquiry into the facts and the widest possible use of exact lnowledge. 


\section{Aiding West Virginia Agriculture Through Research}

7 PROMOTE a better understanding by the farm public of the of agriculture in West Virginia is the aim of this report, which covers the two-year period ending June 30, 1934. The Agricultural Experiment Station, now in its 48 th year, during this biennium has contributed to the welfare of the commonwealth in ways which have returned to the public many times the cost of the work. In this work the Experiment Station has kept abreast not only of the most pressing and immediate problems of the farmer but also of the broad underlying agricu!tural problems, to the end that a more enduring system of farming might be followed by those who draw their living from the soil.

A research program to be of greatest service to the agriculture of the state must be responsive to changing conditions. Many of the problems of today were unknown a few years ago, as, for example, the problem of spray residues, which is now one of the most critical of the many problems related to fruit production. The West Virginia Station has ever been alert to attack new problems and has always maintained a flexible program in order that it might serve where the need was greatest.

\section{REVISION OF THE EXPERIMENTAL PROGRAM}

The rather extensive recasting of the experimental program which was noted in the last biennial report has been continued during the biennium of this report, especially so during the last fiscal year, when the changed emphasis of the new national program made further revision of work desirable. Consequently the project committee was asked to make a critical study of all phases of the experimental program. After an extended series of meetings and conferences with members of the staff the committee presented recommendations for the completion of certain fields of work, the revision of others, and the inauguration of new work in furtherance of new state and national objectives. These recommendations have been made effective. It is believed that the revised research program is now fully attuned to the more pressing emergency problems of the 
state and at the same time provides for such fundamental scientific work as is needed for the solution of long-time problems.

The revised list of projects shown elsewhere in this report includes a total of 66 projects as compared with a total of 76 in the biennial report for 1932, the reduction in number having been made necessary by reductions in appropriations. A total of 17 projects were completed, 13 were revised or combined with other projects, and 46 were continued. New projects adopted within the biennium are as follows:

The effect of rations and methods of feeding grain on egg production.

Battery rations for growing chicks.

Forest tree diseases.

A comparison of loan appraisals on real estate with assessments.

Green manure rotations for upbuilding and maintaining soil fertility in vegetable crop production.

A study of the Charleston area as a market for truck crops and farm produce.

The economic and social development of families in Roane and Wirt counties as affected by the soil-erosioncontrol program.

The causes of fruit splitting in the apple.

Corn silage studies.

Cost and efficiency of milk distribution.

The cost of milk production.

A study of the economic and social progress of homesteaders of the Arthurdale and Tygart's Valley homesteads.

Types of farming in West Virginia.

Cooperation with subsistence homesteads in the production of farm and garden products.

As will be noted the majority of the new projects in the above list deal with problems of particular moment in the present emergency or contribute information needed in future planning. The studies of milk production and distribution, for example, will provide the facts upon which equitable adjustments of milk prices may be based. The studies of homesteading, of types of farming, and of the value of erosion control which are discussed in more detail in another section of the report are further examples in point. 
Cooperation between departments and with neighboring states and various state and federal agencies has received especial emphasis in the new program to the end that all possible duplication might be eliminated and all possible sources of information and guidance might be utilized.

Reference to the complete list of projects will show that 10 are cooperative between departments of the West Virginia Station, 7 are cooperative with the U. S. Department of Agriculture, 1 is cooperative with the Experiment Stations of Virginia, Maryland, and Pennsylvania and also with the U. S. Department of Agriculture, 3 are cooperative with the Department of the Interior, and 1 with the West Virginia Relief Administration.

One of the most far-reaching and potentially valuable studies in the history of this Experiment Station has just been inaugurated as a cooperative project between the Forest Service and the Bureau of Biological Survey of the United States and the biology department of the College of Agriculture and Experiment Station. The project will bring the united forces of the federal agencies and the University to bear on problems relating to the uses of non-agricultural lands in West Virginia with especial reference to the conservation and development of timber lands, recreational areas, and fish, game, and fur-bearing animals. The State Department of Conservation is likewise lending every possible aid to these studies.

\section{INSECT PEST SPRAY STUDIES}

Another project of particular value and timeliness was begun during the spring of 1934 by the Bureau of Entomology of the U. S. Department of Agriculture in cooperation with the West Virginia Station. This involves an extensive series of experiments in the control of codling moth with the particular object of securing a satisfactory substitute for lead arsenate as a spray for apple orchards, a problem which has recently become acute because of increase in codling-moth injury and the setting up of limits of tolerance in foreign and domestic commerce for arsenic and lead as spray residues. The experiments are located in Jefferson county with headquarters at the Kearneysville branch of the Station and are one of four similar series of experiments which the Bureau of Entomology is conducting in important apple regions of the United States. The 
cooperation of the federal agency has greatly expanded our own work in this field and enhanced the chances of an early solution of this important problem.

The establishment of subsistence homesteads at Reedsville and Elkins by the Department of the Interior and at Red House by the State Emergency Relief Administration has created new demands for research in this pioneer field. The Experiment Station is cooperating with both the federal and state agencies in securing information on the social and economic progress of the homesteaders and in experiments dealing with vegetables, field crops, potatoes, small fruits, and soil management as applied to homesteading.

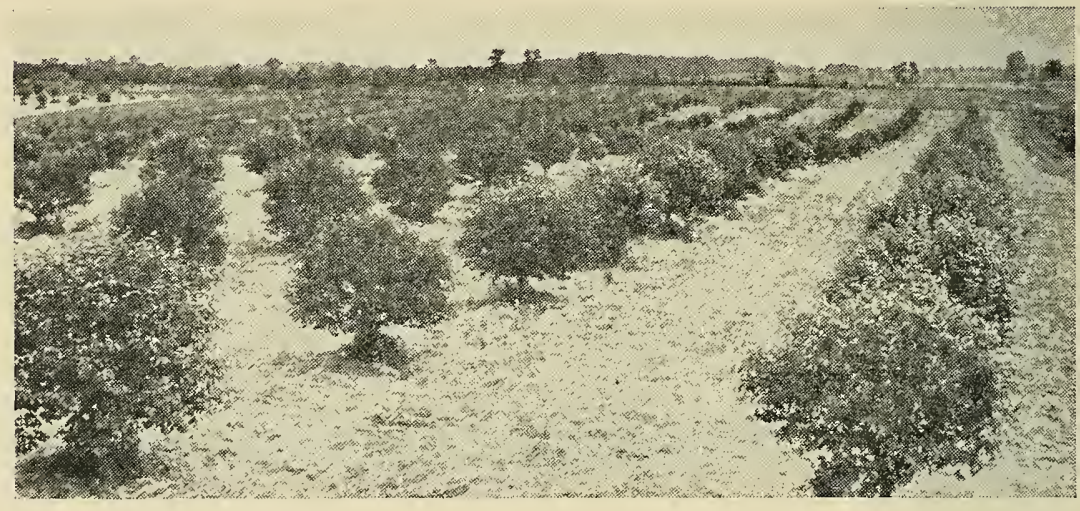

Experimental cherry orchard at the University Experiment Farm, Kearneysville

\section{SOIL EROSION CONTROL}

The establishment by the Department of the Interior of an extensive project on the control of soil erosion in Roane and Wirt counties has afforded an opportunity for studies of the value of erosion control in the social and economic life of the people of that area which the Station has been glad to accept. The studies are cooperative with the Soil Erosion Service.

A study of types of farming in West Virginia recently begun in cooperation with the federal Bureau of Agricultural Economics will provide information as to the more profitable types of farming in different areas of the state and the most economical units for particular farm enterprises. The results will be especially valuable in future planning. 
Reference should also be made to a study of the Charleston area as a market for truck crops and farm produce now in progress with the aid of the State Emergency Relief Administration. Much of the produce consumed in Charleston and the southern coal fields comes from distant points outside the state and the object of the study is to open these markets to more locally grown products.

\section{RESEARCH GRANTS}

Research grants have contributed materially to the research program during the biennium.

The National Research Council has provided a grant to Dr. C. R. Orton for the employment of an assistant in his studies of the watermelon wilt disease, and the DuPont Chemical Company has provided support for Dr. W. H. Pierre's pioneer studies of the residual effect of mixed fertilizers on soil reaction.

A research grant from the Grasselli Chemical Company for studies of new spray materials in codling-moth control has made possible a considerable expansion of the work in entomology under Dr. L. M. Peairs.

\section{COOPERATION IN THE NATIONAL PROGRAM OF ECONOMIC RECOVERY AND RECONSTRUCTION}

Within the biennium the College of Agriculture has participated in many activities of an emergency character designed to promote economic recovery and reconstruction. Practically all members of the staff have contributed in greater or less degree to some phase of emergency work and all units of the College group have worked together so closely that it is scarcely possible to point to specific contributions as the exclusive work of the Experiment Station, the Extension Service, or the staff of resident instruction. Brief mention will be made of those activities which were sponsored chiefly by the Station or in which major contributions were made by members of the Station staff.

A farm housing survey, a study of farm mortgages and land values, and a study of part-time farming were conducted within the period from December, 1933, to May, 1934, in cooperation with various federal agencies, as a part of the reemployment program of the Civil Works Administration. 


\section{THE FARM HOUSING SURVEY}

First-hand information as to present housing conditions, water supplies and sanitation, and of needed repairs and improvements was obtained in the Farm Housing Survey which covered all farms in the counties of Grant, Mercer, Monongalia, Randolph, and Wood, with a total of 9,425 farm homes. In general the houses had been poorly cared for during the past few years because of economic conditions, and many items of needed repairs were noted. Water supplies although usually adequate were often inconvenient. Approximately 80 percent of the families carry their water supplies an average distance of 75 feet, although in most cases running water could have been installed in the homes at slight expense. Sanitary toilets and better lighting and heating facilities were among the most urgent needs.

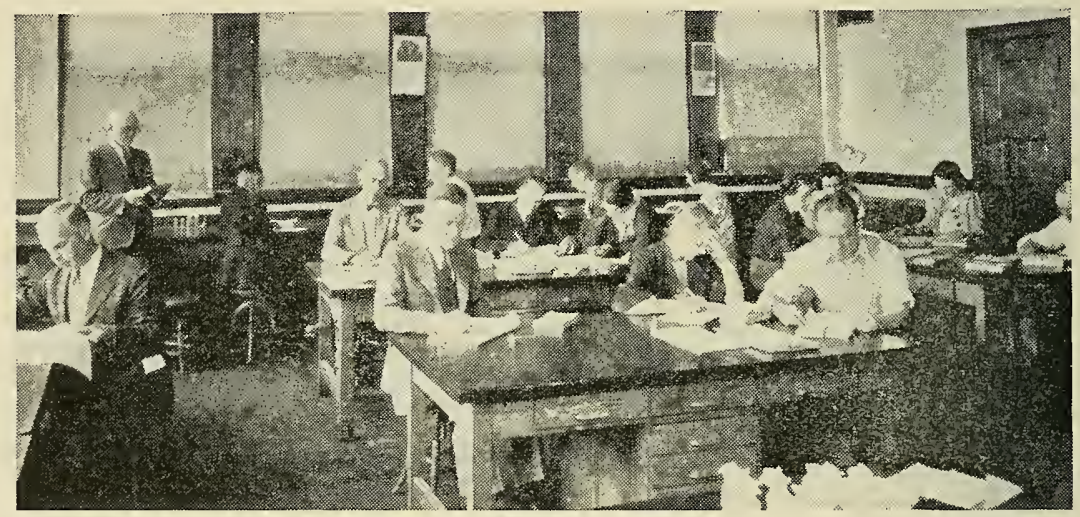

Federal CWA workers checking data in study of tax delinquencies and tax sales of farm lands

Complete data on tax delinquencies and tax sales of all farm lands which had been tax-delinquent at any time in the past five years were obtained in all counties of the state under the project dealing with farm mortgages and land values. Records of land transfers were also obtained in five selected counties. Although conditions were admittedly abnormal during the period covered by the survey the data will afford comparisons as between counties and as between different states, since similar surveys were made in other states.

The study of part-time farming was conducted in selected counties which were considered typical of the principal types of in- 
dustrial employment afforded in the state: Cabell for general industry, Marion for coal and manufactures, Roane for gas and oil, and Nicholas for timber. Data were obtained as to the sizes of farms operated by part-time farmers, the value of land and buildings, the value of products, and the income from sale of products and work off the farm.

\section{SUBSISTENCE HOMESTEADS}

Work preliminary to the establishment of subsistence homesteads and assistance in their planning and operation have made heavy demands on the staff. The soils of proposed homestead sites have been analyzed both in the field and laboratory as to their suitability for homestead farming, and cropping plans have been worked out to provide the needed food and feed supplies. Instruction has been given to groups of homesteaders in special classes. Three homestead units have been established in West Virginia. The homesteads at Reedsville, Preston county, and in the Tygart's Valley in Randolph county are administered by the Department of the Interior, while that at Red House in Putnam County was established by the State Emergency Relief Administration.

Organized homesteading is a new venture in American life with few established guides, and hence presents a multitude of problems for solution through research. With the cooperation of the Department of the Interior the Station has established an experimental area of 30 acres at Reedsville for studies of rotations, maintenance of soil fertility, and varieties of vegetables, small fruits, and field crops best suited to the small farm. Studies of the economic and social life and development of the homesteaders are also in progress.

Closely allied to subsistence homesteading is the program of rural rehabilitation which aims to assist the small farmer now on relief to become economically independent. Members of the Station and Extension staffs are serving on the state committee which is guiding the rehabilitation program in West Virginia.

With the inauguration by the federal Department of the Interior of a program for the control of erosion on the agricultural lands of the country, steps were taken by the state to bring the benefits of this service to West Virginia. Plans for an area of approximately 100,000 acres on Reedy Creek in Roane and Wirt counties were presented to the federal agency and accepted. Work was begun in the late spring of 1934 with Dr. M. M. Hoover, for- 
merly associate agronomist of the Experiment Station, as regional director. The station has maintained a close advisory relation to the project in matters relating to the selection of staff and methods to be used in erosion control. These methods consist chiefly of reforestation, pasture improvement, the use of legumes, and a more rational plan for growing cultivated crops. The project will serve as a demonstration of sound practice in land management and will be applicable to a considerable area of the hill land of the state.

\section{LAND PLANNING IN THE MOUNTAIN STATE}

The full participation of West Virginia in the National Land Planning Program has also been attained through the activities of our Land Use Committee. A preliminary classification of the lands of the state as to future uses has been completed at this time in cooperation with the Land Planning Section of the Agricultural Adjustment Administration, and further work is in progress. The object of this work is to delimit the non-agricultural lands and to plan for their better utilization for timber production, or for recreational uses as parks or game preserves. Agricultural problem areas which require changes in the size of holdings or in management for best use are also designated. The guiding principle of land classification is the welfare of the people, and the land-planning program strikes at the heart of a problem that has become acute in West Virginia. There are many instances of stranded population groups forced to a bare subsistence on submarginal land because of depleted timber or other resources. Reforestation would provide part-time employment for some families, and the movement of others to more productive lands would be encouraged by the adoption of a definite plan.

As a further contribution to land planning each of the important soil types of the state has been rated on a scale of 1 to 10 with reference to the production of the leading farm crops. The work was done by the staff in soils and agronomy in cooperation with the Bureau of Chemistry and Soils of the United States Department of Agriculture, and was made possible by the background of information on soils and crops which has accumulated through the research of the Station over a period of years.

Considerable attention has also been given to the development of plans for the Monongahela Valley Area. The study of forest resources and of fish, game, and fur-bearing animals, which is reported elsewhere, is in part an outgrowth of this activity. 


\section{REPORTS ON CURRENT RESEARCH}

The following reports cover some of the more significant research contributions of the Experiment Station for the biennium 1932-34.

\section{PLANT PRODUCTION}

CULTURE AND BREEDING OF FIELD, PASTURE, AND ORCHARD CROPS

\section{Another New Variety of Soybean}

The increasing popularity of the Pekwa soybean, originated by the West Virginia Station, both in West Virginia and elsewhere, has been reported. Another plant selection made at the same time and from the same variety as Pekwa has been distributed under the name Kingwa. The latter is very similar to Pekwa in yielding ability and in retention of leaves. Kingwa is somewhat less uniform, matures slightly later, and produces rather smaller seeds. The following excerpt from a recent letter from Indiana gives some idea of the extent to which Kingwa is being grown in that state:

"The Kingwa soybean acreage has developed rapidly in Indiana. Our Southwestern growers in the extensive seedproducing area certainly like to grow this variety, as it handles better than the Wilson, Laredo, or Sable and makes an excellent yield."

Of the two strains, Pekwa is the more adaptable to West Virginia conditions.

\section{Two New Varieties of Wheat}

In 1920 more than 2500 head selections of winter wheat were made from the better-yielding varieties growing at that time on the Station Agronomy farm at Morgantown. These were increased and compared for yielding ability and other desirable characteristics until all strains were eliminated except the few better ones. These were further tested both on Station farms and on privately-owned farms. There remain two strains descended from two of the 2500 heads which appear good enough to justify their distribution among farmers in the state. Arrangements for such distribution will be made in the near future. 


\section{Winter Barley}

The acreage of winter barley has been appreciably increased in recent years in certain sections of the state in order to produce more home-grown feed. As a result there is considerable demand for information regarding this crop. Seeding experiments and varietal trials were begun two years ago at Lakin, Kearneysville, and Morgantown. Last year the winter barley seeded during the first week of September gave best results at both Lakin and Morgantown. Tennessee Winter and selections from it are the most commonly grown sorts at the present time (1934).

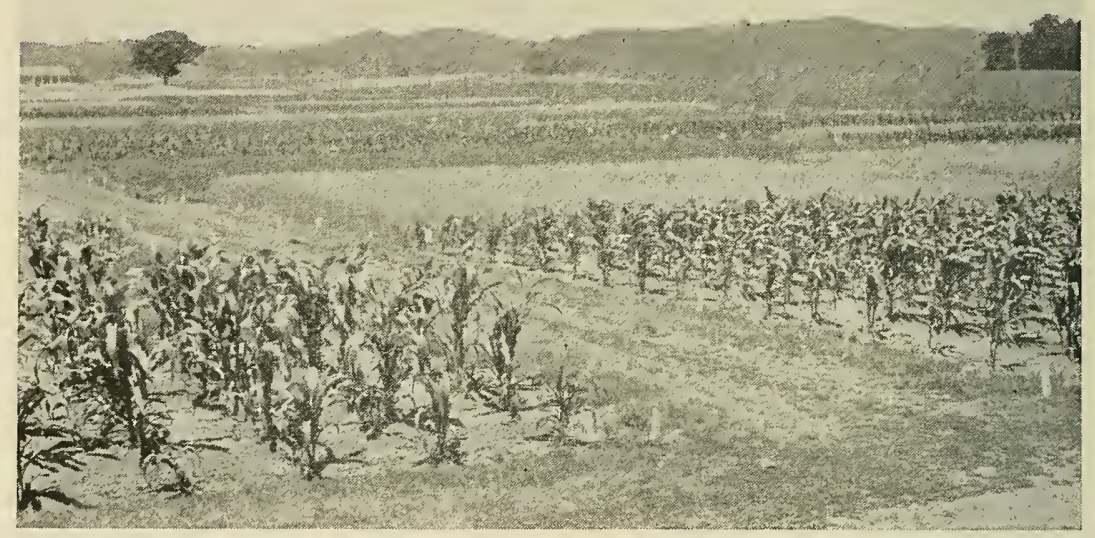

Crops growing on the rotation plots maintained at the Lakin Experiment Farm

\section{Training and Pruning Fruit Trees}

In a study of apple-tree training methods single debudding and group debudding are both producing better trees than by the usual methods of heading at 30 to 36 inches.

Yield records on a block of Delicious apple trees near Martinsburg indicate the production of a higher percentage of large apples on heavily and on moderately-pruned trees than on trees lightly pruned, but there were no significant differences in total yields under the three treatments compared.

Young Montmorency cherry trees have been given four degrees of severity of pruning each year. Moderately heavy pruning seems to be producing, to date, the most desirable type of tree, with good framework and with bearing area about as large as is obtained by any other treatment. 
Rootstocks for Apple and Cherry Trees

From a long-time standpoint one of the vital needs of the fruit industry is better stocks upon which to graft our commercial varieties. This need is probably more acute with the apple and cherry than with other fruits. An extensive experiment to aid in the solution of this problem was begun in 1933 at the University Farm at Kearneysville. The experiment involves 35 rootstocks and ten different varieties-3,354 trees in all. Tree variability, congeniality of stock and cion, tree vigor, hardiness, and disease and insect resistance are being studied.

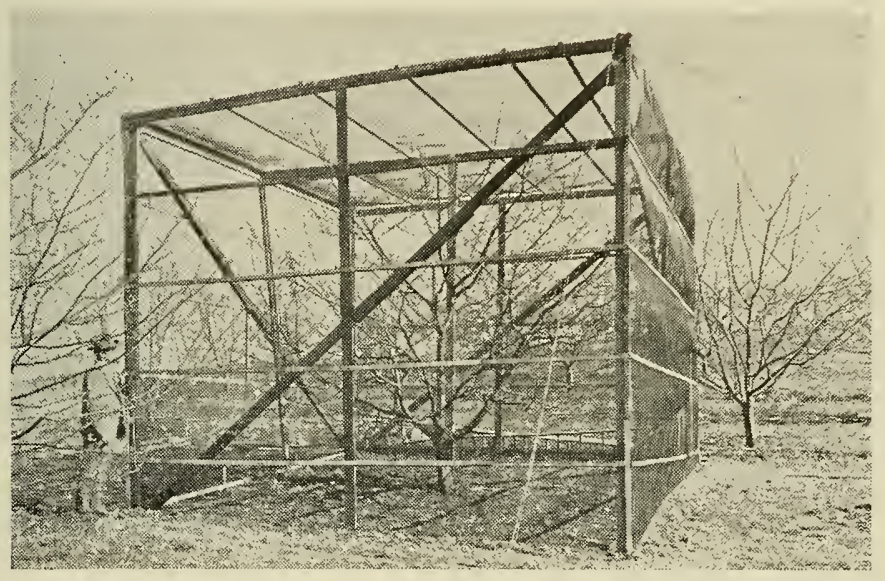

Cage of screened wire to exclude bees in controlled pollination experiments

\section{Fruit Splitting in the Stayman Apple}

One of the serious faults of the Stayman apple is its tendency to crack when near maturity. In some years losses are as high as one third to one half of the total crop in some orchards. The problem has been under investigation for several seasons. Results show that cracking is independent both of changes in soil moisture and of periods of rainfall and that it occurs during periods when atmospheric humidity is such that little or no evaporation takes place.

Tendency to crack was greatly aggravated by the presence of russeted areas, scab lesions, and sunscald on the fruit surface. Freezing-point determinations of apple tissue showed a higher osmotic value in regions prone to crack. Cracking was more severe on trees or branches with sparse or spray-injured foliage. 


\section{Color in the Apple}

A full knowledge of the chemical nature of the pigment in apple skins would be of much value in helping to determine and evaluate the intricate physiological processes whereby nature colors the apple as it ripens. Knowledge of these processes in turn may lead some day to a partial control of the factors involved and to those orchard practices best suited to the production of high-color and highquality fruit. Physiological changes accompanying and affecting the

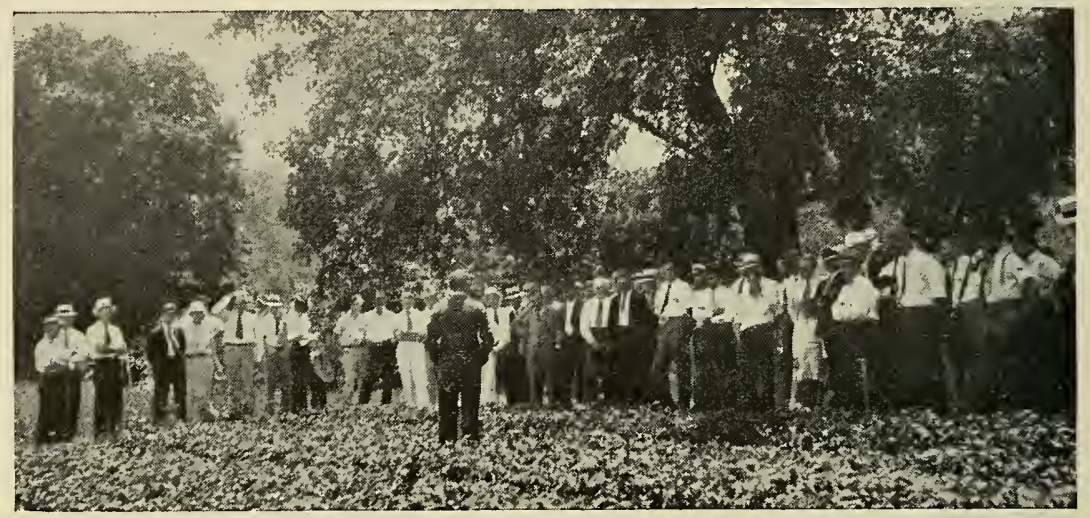

Field Day visitors inspecting strawberry plots at the Lakin Experiment Farm

coloration and ripening processes are being studied. Already an interesting outgrowth of the general problem has been a study of the effect of certain stimulating agents such as ethylene and ethylene chlorohydrin on stored apples. It has been suggested that treatment of apples with ethylene might be used to increase their sugar content, but trials with stored apples in the laboratory failed to enhance either color or sugar content. The rate of change from green to yellow was hastened by ethylene treatment as was also the rate of softening of the apple tissues.

\section{Picking Cherries at the Proper Time}

Within the past seven years about 300 acres of Montmorency sour cherries have been planted in the Eastern Panhandle of the state mostly by farmers having little previous experience with the cultural requirements of the crop. When these trees began to bear it was found that there were no maturity standards for harvesting; consequently most growers picked the fruit at least seven days before 
full size and best quality were reached. Trials in 1933 and 1934 have clearly demonstrated that this variety may be left on the trees several weeks longer than has been done in the past, with continned increase in size and quality.

\section{II ardiness of the Fruit Buds of the Peach}

One of the limiting factors in peach production in this state is the loss due to bud killing in late winter and early spring. In a test of 60 varieties the following have been found markedly resistant to low winter temperatures: Golden Jubilee, South Haven, Rochester, and Salwey. Cultural treatments are also being investigated as they affect hardiness.

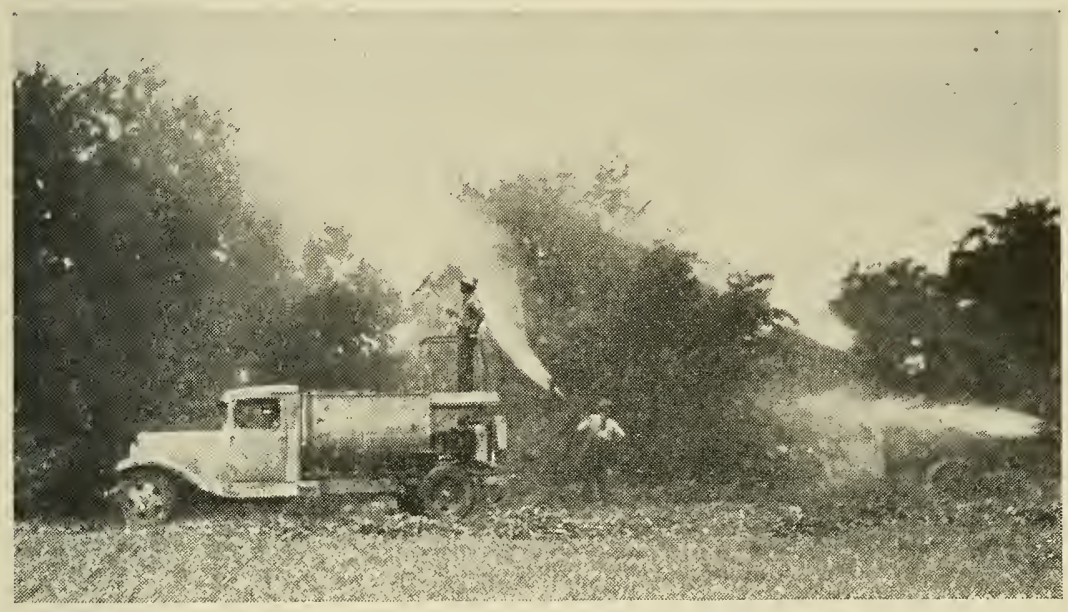

Spraying in codling-moth experimental work

\section{Varieties of Horticultural Crops}

From 150 to 200 varieties and strains of the common vegetables are tested at Lakin Experiment Farm each year in order that growers of the Ohio-Kanawha Valley section may learn of the varieties best adapted to their soil and climatic conditions. Varieties outstanding during the past several years are: Break-O-Day and Pritchard tomatoes; Early Wonder and Ohio Canner beets; Marion Market cabbage; Golden Cross Bantam, Vanguard and Evergreen Hybrid sweet corn; Milwaukee Market and Benders muskmelon; strains of Fordhook bush lima beans. 
With the greater interest being displayed the past two years in the growing of small fruits, it has been necessary to determine what varieties are best adapted to the state. In a test of varieties of strawberries at the Lakin Experiment Farm, Premier, Blakemore, Fairfax, and Gandy have been found superior. In the grape vineyard at Morgantown Fredonia, Portland, and Sheridan have been worthy of recommendation along with Concord, Niagara, and Delaware. Variety trials at Morgantown and the Reedsville Experiment Farm are being carried on with red and black raspberries and with blueberries.

Several hundred varieties and strains of tree fruits are on trial at Morgantown and at Kearneysville. New varieties worthy of trial are: Stanley, Hall, and President plum; Golden Jubilee, South Haven, Delicious, and Cumberland peach; Lincoln pear; Chase and Gold cherry; Lowry, Red Willow, and the red strains of Delicious, Stayman, and Rome apple.

\section{MAINTENANCE OF SOIL FERTILITY}

\section{Residual Reaction of Fertilizers}

One of the most outstanding contributions of the Experiment Station during the past biennium is the development of a laboratory method for determining the residual effect of fertilizers when applied to the soil. Some fertilizers leave an acid residue which is harmful to most cultural crops; other fertilizers leave a desirable alkaline residue; and still others do not affect soil reaction. By means of a rather simple method which has been developed it is possible to determine beforehand the effect on soil acidity which any fertilizer will produce. In the past there has been no means of determining the value of fertilizers from this standpoint.

The method makes it possible for fertilizer manufacturers to prepare fertilizer mixtures which will have a known residual effect on the soil reaction. Inasmuch as fertilizers which leave an alkaline or neutral residue are preferred for most crops, the tendency will be for manufacturers to produce such fertilizers by substituting finelyground limestone for sand or other inert material which now is used as filler but is of no value to the farmer. The method also makes it possible, through slight changes in state fertilizer laws, for farmers to know what effect any fertilizer will have on the acidity of the soil. One state has already enacted a law requiring that fertilizer labels must show not only the plant food elements the fertilizer con- 
tains but also the effect it will have on soil acidity. It is perhaps needless to point out that farmers, particularly those of the eastern United States, would much prefer a fertilizer that leaves an alkaline or neutral residue than one that increases soil acidity.

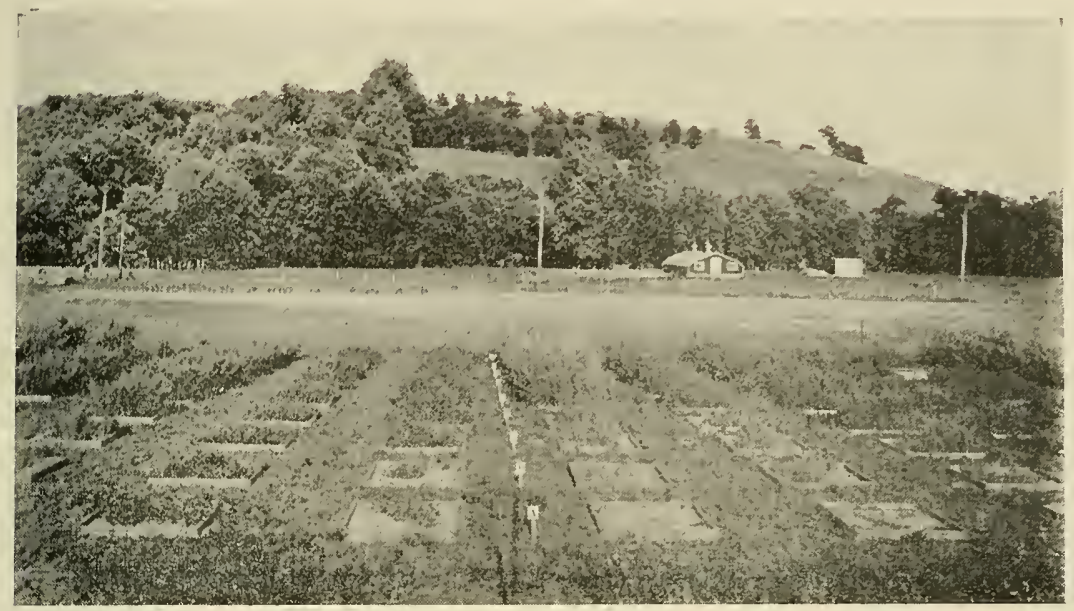

Small frames enable soils scientists to determine the amounts of lime required by different crops. Left to right (four rows): alsike, red clover, sweet clover, alfalfa. Note improved growth of legumes as amounts of lime added increase from front to rear. Front plots received no lime

\section{Pasture Fertilization}

It has been shown in comprehensive investigations begun in 1930 in cooperation with the U. S. Department of Agriculture that pastures on most soils may be much improved by lime and various fertilizers. The improvement is measured by the increased herbage, the changed character and composition of the herbage, the increased length of the grazing season, and the residual effect of the lime and fertilizer over a period of years. At the Reymann Memorial Farm measurements of pasture improvement are being made with dairy cows and heifers and also by weighing the pasture clippings and studying the flora, whereas in the other and outlying experiments only the latter two methods are being used to measure differences. Thus far a rather high correlation has obtained between results with grazing animals and those from clipping the plots with a lawn mower.

A comparison of results in 1932 and 1933 at the Reymann Memorial Farm emphasizes the importance of plant competition. 
During the former year when White Dutch clover was present, the use of phosphorus, potash, and lime increased the yield 96 percent, while the addition of nitrogen increased the yield from 5 to 17 percent. In contrast to this, the following year, when the clover had disappeared, the use of phosphorus, potash, and lime increased the yield only 20 percent, whereas the addition of nitrogen increased the yields from 17 to 70 percent.

Summer applications of nitrogen during dry seasons gave no response, but in more favorable seasons marked responses were obtained and the grazing season appreciably lengthened. The extent of nitrogen recovery in the herbage was found to be greatly influenced by the amount of clover present. Where large amounts of clover were present no more nitrogen was recovered from plots fertilized with this element than from plots that did not receive it.

\section{Cultural Treatments and Fertilizers for Fruits}

Sweet clover, alfalfa, vetch, and orchard grass sods are being compared with clean cultivation followed by winter rye cover in peach, cherry, and apple orchards at Morgantown and Kearneysville. Other systems under trial are double clover (soybeans and rye) and sod rotation. To date sweet clover has been found superior to other covers in its effect on growth and yield of apple trees in culture tests at Paw Paw.

In tests of different forms of nitrogen for apples, cyanamid has been found to give as good results as nitrate of soda.

\section{Potato Fertilizers and Cover Crops}

The potato requires large amounts of soil nutrients if high yields are to be obtained. In 1933, trials near Reedsville showed that one ton of a 5-12-7 fertilizer broadcast at planting time gave the best results. Halving or doubling the nitrogen had no significant effect on yield. This year extensive fertilizer trials have been initiated on 12 soil types in different sections of the state. Results from this experiment should be extremely valuable to the potato growers of the state.

During the season of 1932 at Lakin a marked increase in the yield of Number 1 potatoes was obtained as the result of turning under various cover crops. This was true even where liberal applications of fertilizers were used. The cover crops grown and compared were rye alone, a mixture of rye and hairy vetch, and soybeans followed with rye and vetch. 
Many commercial orchards in the Eastern Panhandle are situated on shallow soils and have suffered severely in drought years. It has been thought that breaking up the subsoil would allow roots of trees to penetrate to greater depth and so tap reserves of moisture which otherwise would not be found. Trials carried on by subsoiling or dynamiting to a depth of 18 to 36 inches in orchards near Martinsburg, Romney, and Morgantown have shown no benefits to date. Similarly, yields of potatoes in trials at Kearneysville have failed to show marked response to deep tillage.

\section{PLANT PROTECTION}

\section{CONTROL OF INSECT PESTS}

\section{Lead Arsenate Substitutes in Codling-Moth Control}

Increase in the codling-moth population in the commercial fruit areas of the state due to favorable weather conditions and to a restricted spray program has necessitated that much attention be directed to the study of this insect. The problem has been made more difficult by the establishment of regulations concerning arsenical and lead residues. Arsenate of lead has been the standard control material for many years and no adequate substitute has been developed.

During the season of 1933 a considerable number of possible substitutes for lead arsenate were tested. These included other arsenicals, one non-arsenical copper compound, and several plant derivatives. Calcium arsenate was found sufficiently effective to give control where infestations were not severe, but in the heavily-infested districts it was inadequate. Other materials tested gave negative or inconclusive results.

Cooperative agreements with a commercial concern and with the U. S. Department of Agriculture, Bureau of Entomology, have permitted a considerable extension in the program of experimental work at Kearneysville including the testing of new proprietary materials and non-metallic poisons. In addition the Station has conducted a number of tests of available arsenical poisons which seem to be possible substitutes for lead arsenate.

Although preliminary results indicate that some of the materials used will compare favorably with arsenate of lead, it still seems cer- 


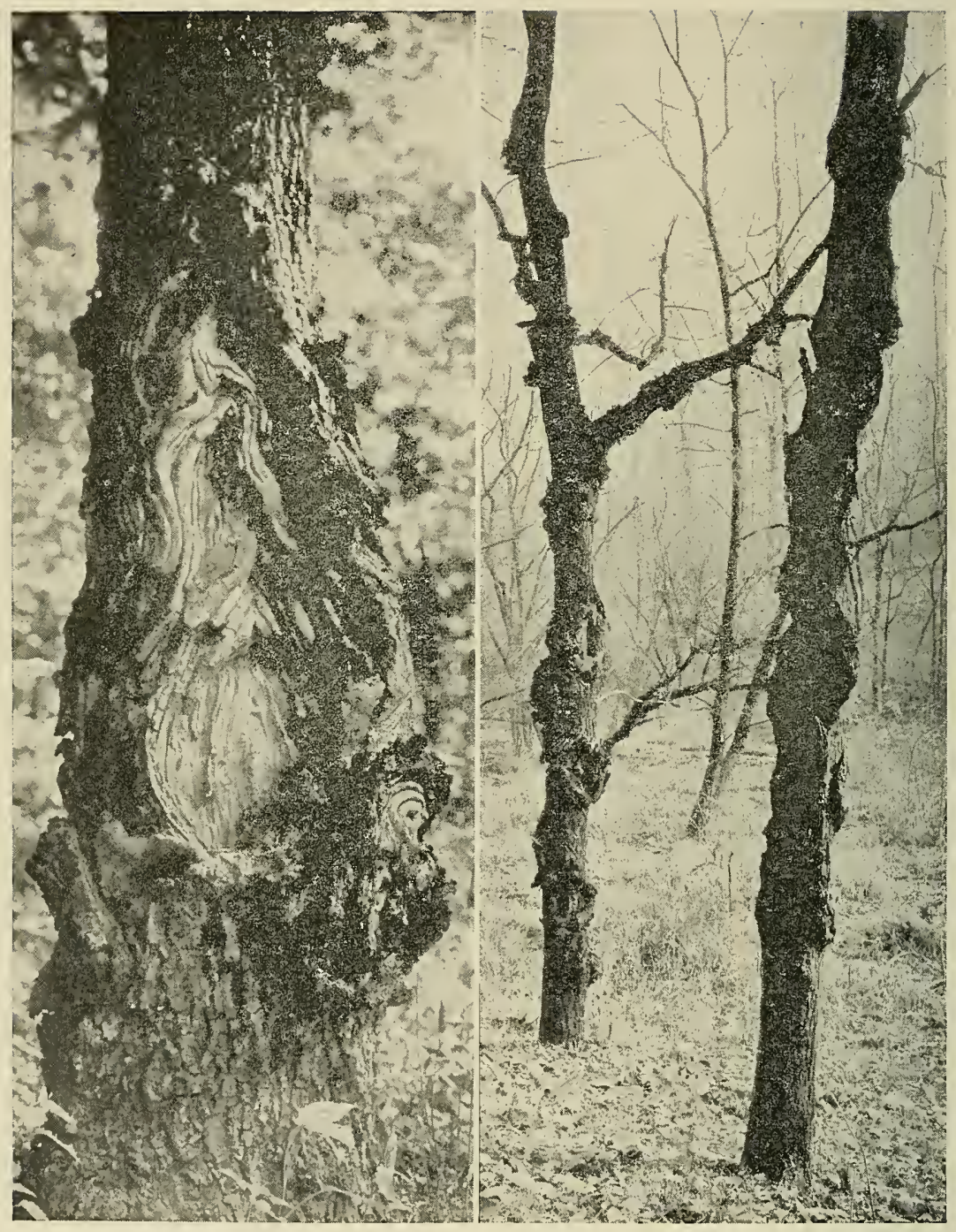

Left-Large canker of black walnut with heartwood exposed. Right-Black walnut trees with numerous cankers on trunk and limbs 
tain that the latter material with a proper adhesive will continue in common use and that the practice of washing the fruit at harvest time must continue.

\section{Bait-Pails and Bands}

Accessory lines of work in connection with the codling-moth problem have included the use of bait-pails to trap moths and obtain information which will permit the proper timing of the spray applications and the use of treated bands to destroy the worms or larvæ. The practice of using bands has developed from no more than a few experimental-demonstration blocks arranged by the Station in 1932 to the actual commercial use of several hundred thousand feet of bands by the growers in 1934. The benefits from banding are cumulative and may be expected to demonstrate their value increasingly from year to year.

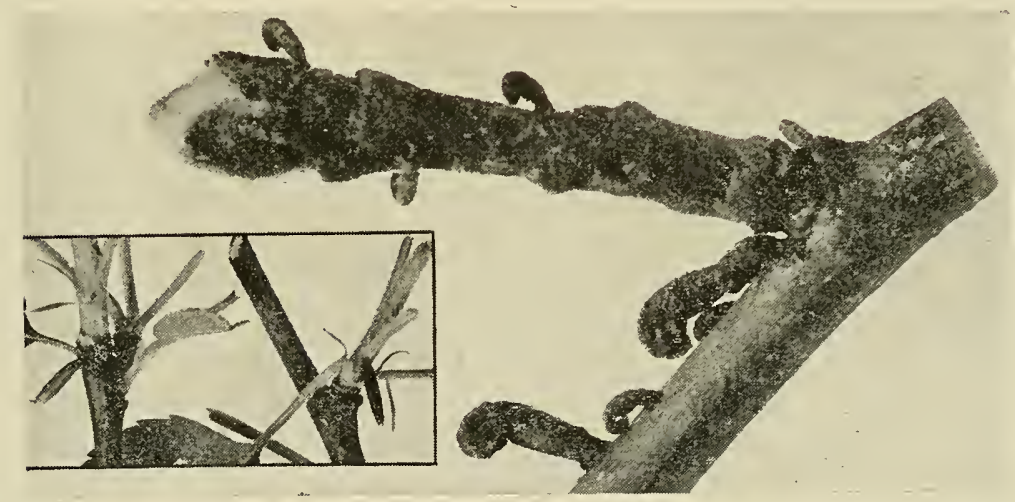

Pistol case-bearer on twig of apple; insert, the slender objects at the bases of leaves are the cigar case-bearer

\section{Aphids}

Apple-aphis studies indicate that the best control is obtained with sprays containing cresyllic acid applied during the delayed-dormant season in the spring rather than during the winter. The cresyllic-acid combinations have practically replaced lime-sulphur for aphis and, when they contain oil, for scale. This results in a considerable saving for the growers and is much more certain control of the insect. 


\section{Pistol-Case Bearer}

Studies of the control of the pistol-case bearer have continued. It has been shown that certain oil-spray combinations applied in the spring will give adequate control and may replace the summer appliation which has been recommended. A rather general decrease in the damage from the insect indicates that it is being brought under satisfactory control. Efforts to determine the cause of the outbreak are being continued, part of the work along this line being the study of the parasites of the insect.

Ten years ago the pistol-case bearer was a curiosity in the orchards of the state. Its near relative, the cigar case bearer, occurs in many localities but has not yet done commercial damage as it has in other states. No reason is known why it may not at some time develop into a pest of importance just as the pistol-case bearer has done. Part of the work of the Station is to observe such potential pests and to attempt to forestall any tendencies toward unusual increase in abundance.

Stationary Spray Systems in West Virginia

In a survey of all stationary spray plants in West Virginia it was found that the use of more pipe, one-man crew, and shorter hose lengths makes for greater efficiency and economy in spraying from stationary plants.

The timeliness of the spraying operation is one of the chief advantages of the stationary system. Topography and soil conditions are not limiting factors in this method of spraying.

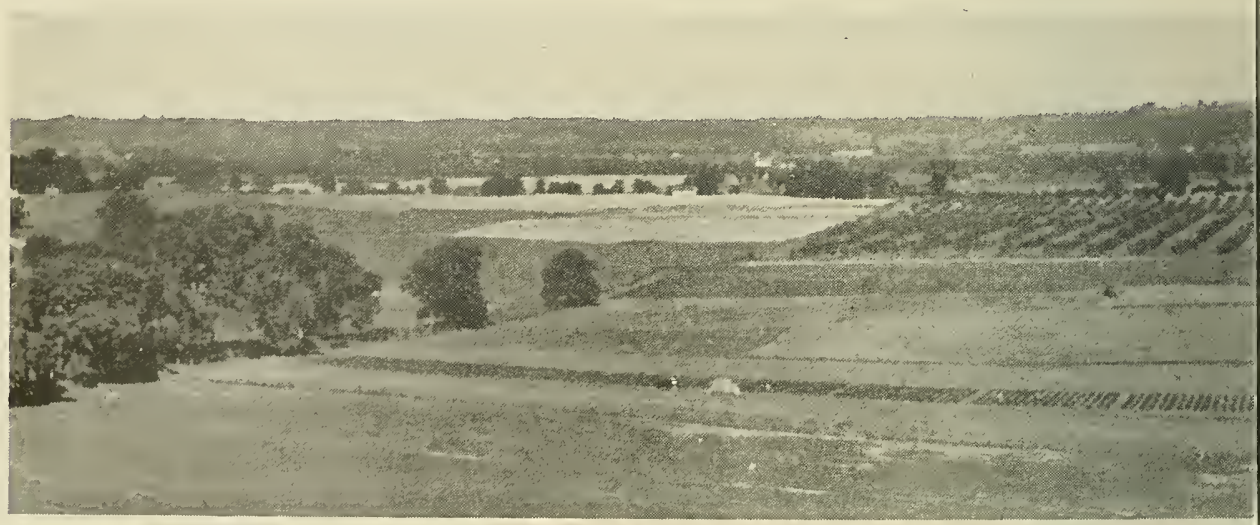

General view of Lakin Experiment Farm. The vegetable 
The initial cost of the stationary system for orchards of commercial size need be no greater than the cost of complete portable equipment. With only one engine and one pump necessary, and these stationary, maintenance, operation, and repair of the mechanical units are greatly simplified. Most stationary systems are now operated under pressures ranging around 600 pounds.

The quantities of spray materials applied per man hour were greater where stationary systems were used than where orchards were sprayed with portable equipment.

\section{Mexican Bean Beetle}

Among several new materials tested for Mexican bean beetle control the fluorine compounds in the form of natural cryolite, applied usually as a dust, and barium carbonate, applied as a dust or as a spray, show some promise. For emergency use and where expense is not considered, no material equals the pyrethrum compounds, which have the distinct advantage of being non-poisonous to man, so that they may be applied to beans which are nearly ready to harvest. This advantage is claimed also for barium carbonate.

Biological studies of the insect indicate that it is as likely to suffer from conditions obtaining during mild winters as from the more severe winters. During mild winters the beetles leave their shelter on warm days and fail to protect themselves adequately for the cold nights while in the more severe winters they continue their hibernation until weather conditions are settled in the spring.

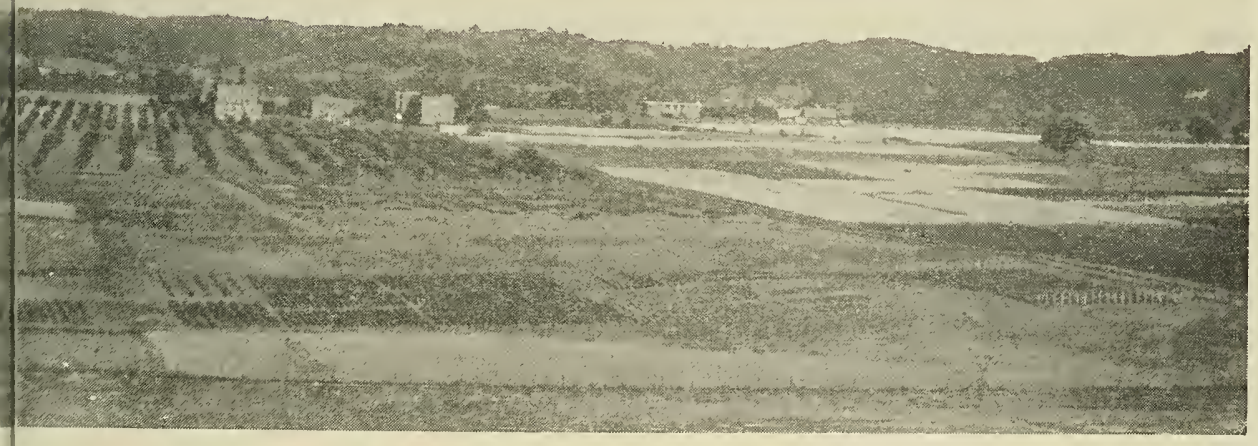

Hts are seen in foreground; agronomic plots are at right 


\section{Black-Pox of the Apple and Similar Diseases}

One of the bark diseases of apple previously known as measles and of unknown nature has been shown to be caused by an undescribed fungus which has been named Helminthosporium papulosum. This disease, which we now call black-pox, is of considerable importance in certain restricted localities but apparently not of general distribution. It has also been found in one instance on the fruit of the Grimes variety.

It has been possible to distinguish clearly from black-pox a second disease which has also been known as measles and which occurs most frequently in plantings of Delicious and its relatives and less commonly on Grimes, Rome, N. W. Greening, Jonathan, and King David. The specific cause of this disease is unknown. It is apparently more severe and of more general distribution than blackpox.

A third type which is believed to correspond closely, if not being identical, with the original disease described as measles has been found rather widely distributed on several varieties. Its cause is also unknown. It seems to be of lesser importance than the two preceding types and has been observed on mature trees which appear unthrifty.

\section{Black-Walnut Canker}

It has been shown that the fungus Nectria galligena causes this important disease of black walnut. The same fungus causes a disease on oak, hickory, and butternut, the last host being relatively resistant. The disease is widely distributed throughout the Allegheny area, extending north into Pennsylvania and south into Tennessee, Virginia, and North Carolina. It is apparently identical with the similar canker of fruit trees and other hardwoods in Europe, which suggests its introduction from that continent. From a study of old cankers the date of introduction would be near the close of the Nineteenth Century. The disease has become so prevalent in the Alleghenies that federal agencies have initiated studies throughout the area on a number of additional hosts. A bulletin setting forth the details of the investigations in West Virginia has been published. 


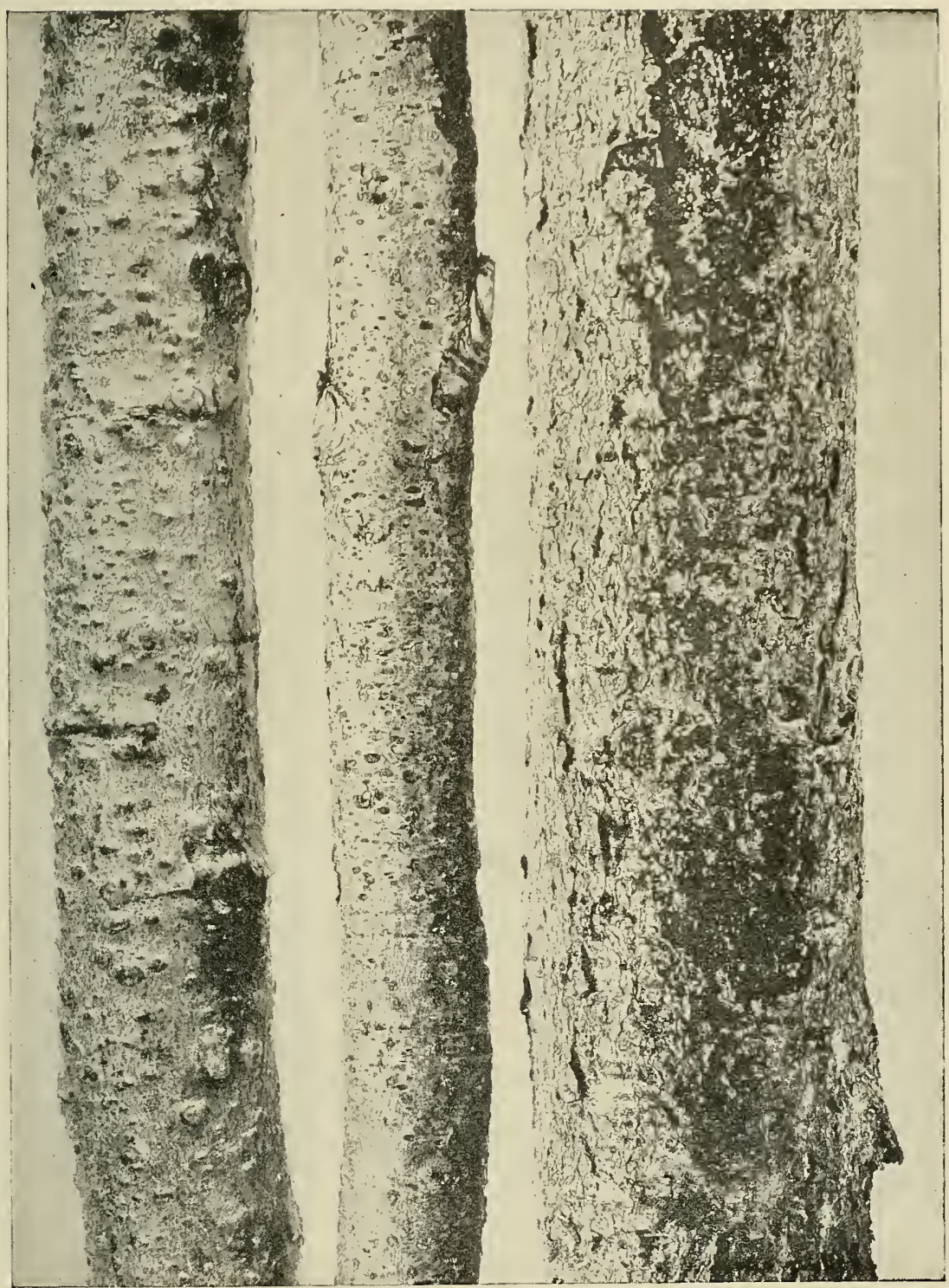

Scaly and pitted bark on older limbs of apple tree affected with black pox 


\section{Watermelon Wilt Fungus}

It has been demonstrated that the reason why wilt-resistant varieties of watermelons developed in other regions fail to show resistance in the Ohio Valley is due to the presence of different strains of the causal fungus, Fusarium niveum. No two strains of this fungus are identical in their ability to cause wilting of any particular variety of watermelon. Varieties must be developed which are resistant to the local strains of the fungus. Furthermore, some strains of the fungus produce new strains rather frequently which vary in their ability to produce wilt in any given variety of watermelon.

\section{Rust-Resistant Red Cedars}

Recent tests have shown that certain red cedars are naturally resistant to rust. Cuttings from selected cedars, both rust-infected and rust-free, were grafted on nursery stock. They were exposed to heavy infection in the orchard. The grafted trees from the rustfree parents remained rust-free, while those from previously infected parents were very heavily rusted. Such resistant trees should be suitable for planting in apple areas where the culturing of susceptible red cedars is objectionable.

\section{Comparative Studies of Bordeaux Mixture}

In suspension tests of Bordeaux mixture, Instant Bordeaux prepared from pulverized copper sulphate and superfine chemical hydrated lime gave considerably higher average suspensions than Bordeat1x prepared from stock solutions of copper sulphate and quick lime or from plasterers' lime. Its toxic properties have been found equal to those of Bordeaux mixture prepared from stock solutions.

The advantages of the method used to make Instant Bordeat1x are: elimination of the cost of special mixing plants; time-saving elimination of stock solutions and greater ease of preparation; actually cheaper cost than Bordeaux mixture prepared from stock solutions. 


\section{ANIMAL PRODUCTION}

\section{LIVESTOCK MANAGEMENT}

\section{Creep-Feeding vs. Dry-Lot Fattening}

In a test of the possible advantages of creep-feeding over drylot fattening, begun in Greenbrier county in the spring of 1933 in cooperation with the Bureau of Animal Industry, U. S. D. A., 30 grade Hereford cows and their 2-months-old calves were divided into two equal lots. The Lot I calves had access to a grain mixture of 8 parts coarsely-ground corn and one part cottonseed meal, fed in a creep to exclude the cows. The Lot II calves received no grain but gained well because of excellent pasture conditions. On November 10 of the same year, pasturage was terminated. The Lot I calves, having eaten 510 pounds of grain per head and having an average

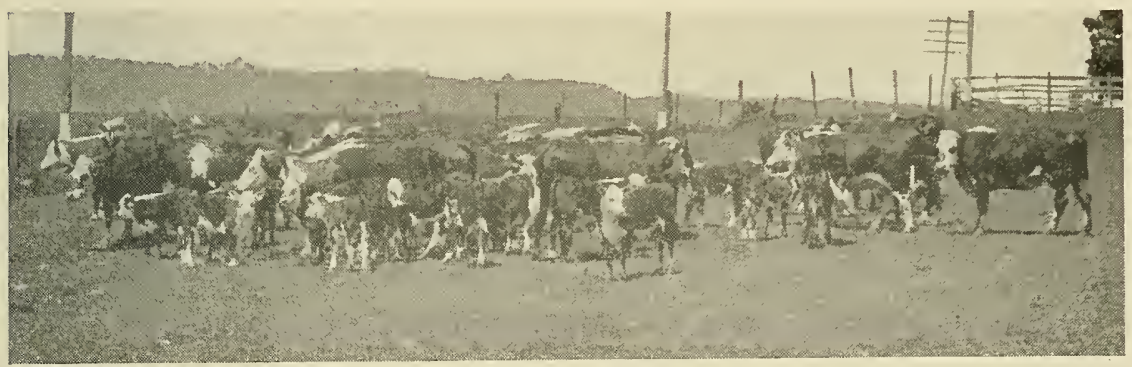

Group of cows and calves in experiment at Lewisburg, photographed just before turning on pasture

weight of 528 pounds, were shipped to Baltimore and sold for slaughter at $\$ 6$ a cwt. This gave them a farm value of $\$ 27.73$ per head at age of $71 / 2$ months, while the Lot II calves, appraised at $\$ 4.50$ a cwt., were credited with a value of $\$ 21.51$. The test indicates that the creep-fed calves more than returned the cost of the grain they ate.

During the following four months until March 2, 1934, the Lot II calves in drylot received each 964 pounds of the grain mixture and 374 pounds of alfalfa, with a gain of 139 pounds. When sold at weight of 619 pounds and age of 11 months they were credited with a farm value of $\$ 33.58$ each, thus returning $\$ 12.58$ for their keep after consuming twice as much feed as the Lot I calves. The latter at age of $71 / 2$ months had returned $\$ 12.22$ each to pay for the use of pasture and the investment in breeding stock and equipment. 
This first test was made when beef prices were extremely low. With higher beef-cattle prices a different outcome may reasonably be expected from a second test, now under way.

Finishing Steers on Grass

Work which has been in progress for several years in Greenbrier county and other work which was finished in Morgantown in the fall of 1933 has shown that two-year-old steers can be sufficiently finished to produce excellent carcass when fed comparatively small amounts of grain (composed of 6 parts of corn and 1 part of cottonseed meal by weight) in conjunction with pasture. One carload of grain thus will finish approximately four carloads of steer.

Since grass alone will not finish steers of this age, the experiment shows plainly that farmers of this state can put two-year-old steers on the market as finished cattle rather than sell such steers as stockers or feeders.

The average weight of steers used in this work was approximately 600 pounds the first half of December, when they were started on winter feed. They were marketed around November 1 the following year, or after a period of a little more than ten months. With a finished weight of more than 1100 pounds, their average gain exceeded 500 pounds.

\section{Grass Does Not Produce a Dark-Colored Beef}

For many years markets have discriminated against the color of grass-fat cattle. Over the past few years work has been conducted in connection with the finishing of cattle on grass alone, grass in connection with grain, and grain alone. Color studies have been made on more than 220 carcasses and the results clearly point to the fact that grass is not responsible for the dark color of beef. It was found in this work that cattle with more finish are as a rule somewhat lighter in the color of lean than thinner cattle. Cattle of the same degree of finish, whether produced by grass or grain alone, showed the same relative color of carcass. Occasionally a dark-colored carcass was found within a group of steers regardless of the kind of feed fed.

\section{Corn-Silage Studies}

The relative merits of silage made from Cocke's Prolific, an ensilage corn, as compared with that from a high grain-yielding variety such as Boone County White, are being investigated in the wintering of beef cattle at Morgantown. The ensilage from these two varieties was fed to two lots of yearling steers on the basis of 
an equal amount of dry matter, determined by chemical analysis, and also to two lots of heifer calves, fed equal amounts by weight. In addition both steers and calves received equal amounts, within their groups, of other feed. The first year's work indicates a superiority of the ensilage made from the grain variety of corn in the case of both the steers and the heifers.

\section{Trends in Fine-Wool Sheep Production}

Analysis of the records of 37 sheepmen who cooperated with the Experiment Station in a cost study shows among other things that from the standpoint of returns on labor and on investment the most profitable amount of roughage to feed is between 50 and 150 pounds per sheep. Wool production increases slightly as the amount of roughage fed increases. This should not be considered as conclusive evidence that any flock in order to be profitable should be fed less than 150 pounds, as a number of flocks returned a profit on larger amounts. Many other factors such as the kind of season, amount of winter pasture, kind of roughage, and kind and amount of grain all influence the amount of roughage to be fed per sheep. In some flocks it appears that a good mixed hay or some legume hay could be substituted for a portion of the grain being fed.

The results of the investigation when submitted to the cooperators tended to hasten the trend of the producers to substitute other types of livestock and sources of income for fine-wool sheep. In some cases this trend was from a change of wethers and low-wool production toward higher weights of wool per fleece and to crossbred lambs. With fine wool selling for the same price or less than coarse wool per pound, the trend should be toward producing lambs as well as wool on those farms suited to sheep production.

\section{Corriedale Rams and Native Ewes}

Evidence that the use of Corriedale rams on native ewes of grade Hampshire type results in a greatly increased yield of wool from the first-cross offspring continues to accumulate as a result of breeding trials begun in 1930. The West Virginia Station and the Animal Husbandry Division, Bureau of Animal Industry, U. S. D. A., are cooperating in the investigations carried on at Hillsboro, West Virginia, Beltsville, Maryland, and Washington, D. C. The work has progressed to the point where it may definitely be stated that the mating of Corriedale rams with grade-Hampshire type ewes has produced daughters that are the equal or superior of their dams in body conformation and that yield as much as 80 percent increase in 


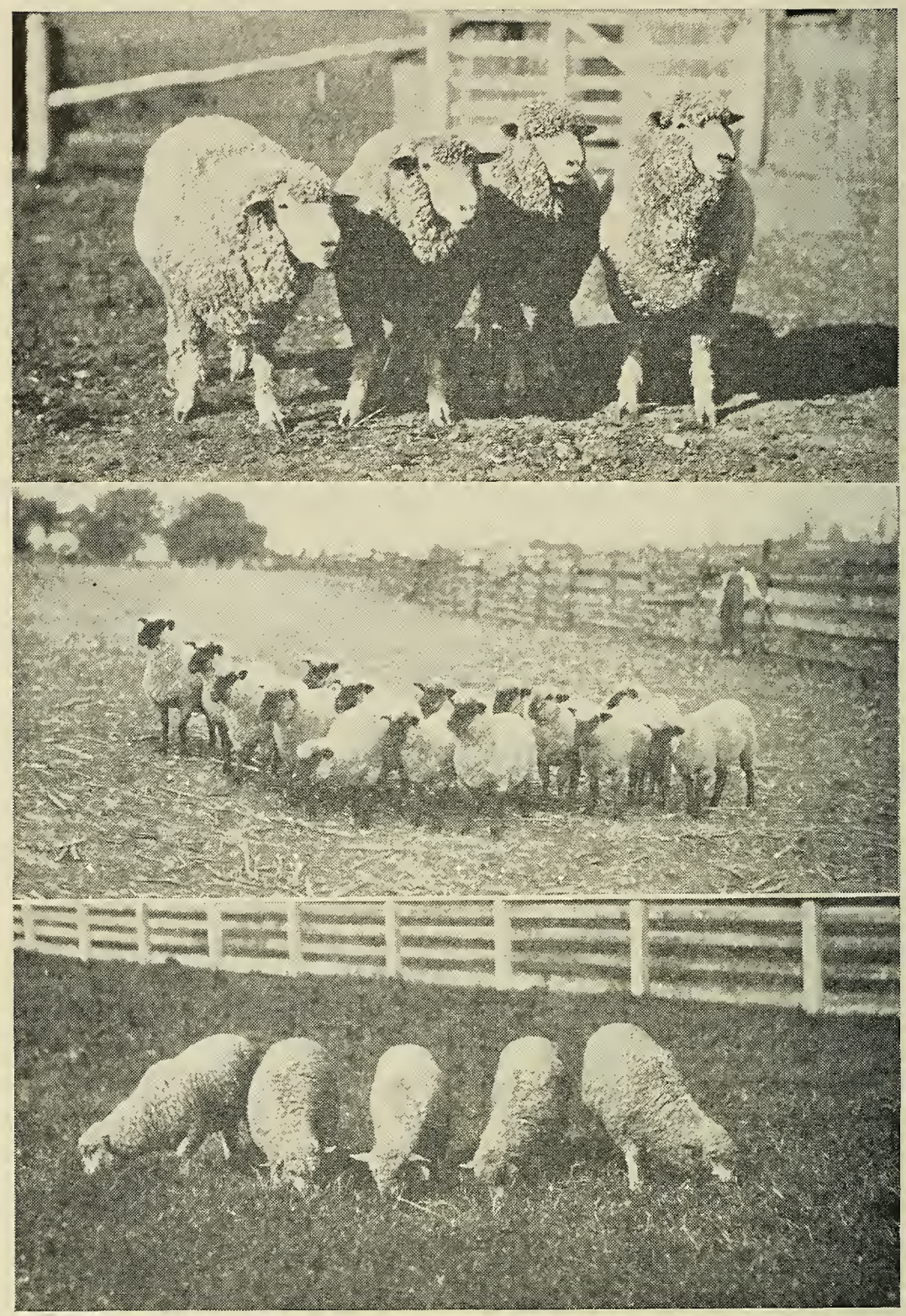

The purebred Corriedale sires, the grade Hampshire-type dams, and typical first-cross offspring. Note the mutton form and light faces of the lambs 
grease-weight wool. The wool is equal in fineness to that of the dams and approximately one inch longer for one year's growth.

A study has been made of the Corriedale-sired wether lambs produced from the grade-Hampshire type eives as to how they compare with wether lambs out of the same or similar ewes sired by purebred rams of the down breeds. All lambs have been slaughtered and carcasses graded at Beltsville. The results definitely show that the Corriedale-sired lambs compare very favorably with lambs sired by either Shropshire or Hampshire rams.

Cooperative studies are being continued on the first-class ewes and the results so far indicate that these ewes are more easily handled than their mothers and should be equally valuable as lamb producers. The first-cross ewes have proved to be very hardy and thrifty. Since these results have been given to the farmers of the state the demand for Corriedale rams for use in improving the native ewes of the state has increased markedly. Additional studies are being continued in order to get information as to the suitability of sheep of the Corriedale type in other sections of the state and the use of Corriedale rams on different types of native ewes.

\section{Control of Stomachworms and Lungworms of Sheep}

One of the problems confronting the sheep husbandman of West Virginia is the control of parasites, particularly stomachworms and lungworms. In 1929 the Station began a study of a number of drugs used in removal and control of intestinal parasites from sheep. These experiments indicate that drenching with a $11 / 2$ percent solution of copper sulphate, administered at intervals of 21 days, is effective in the control of stomachworms, tapeworms, nodularworms, nematodirus, and cooperia. A bulletin giving the details of this work together with the results and conclusions is in press.

Mass feeding of a mixture of copper sulphate and salt was also tried on approximately 140 head of sheep as a means of control and eradication of gastro-intestinal parasites. After feeding about one year on this mixture, losses began to occur from copper poisoning. A reduction of the copper content in the mixture resulted in the development of parasites in the sheep.

More than 50 head of sheep have been systematically treated with an oily preparation of pyrethrum for the removal of lungworms. Although satisfactory results have been secured with the solution now used, additional work will be necessary before definite recommendations can be made. 


\section{POULTRY IMPROVEMENT}

\section{High Production Over Several Years Possible}

By testing the breeding value of many males each year through a careful check of their progeny and by the use of breeders of proved ability to produce high-yielding offspring, definite improvements have been made.

In this work special emphasis has been given to selection for longevity and continued production in addition to high first-year production. In the flock to date one hen has completed her fifth year with a production of 1013 eggs, five hens have completed their fourth year with an average of 816 eggs, and 16 hens have completed their third year with an average of 626 eggs. Twenty and two-tenths percent of all Leghorn pullets begun in 1933 finished their year with a production of 225 or more eggs, which weighed 2 ounces or better.

This work indicates the importance of breeding stock as the foundation of economical egg production. Farmers buying baby chicks should know something definite of their parentage before making purchases.

\section{Age Affects Egg Yield and Egg Weight}

In an experiment started in 1925 to study egg production, egg weight, and body weight during the normal life of White Leghorn hens, the average annual egg production has decreased 23 percent each year. The average weight of eggs increased until the third year and gradually decreased after the fourth year. Age appears to have the greatest influence on egg production and egg weight. High annual production did not decrease the average weight of eggs. High or low first-year egg production had little effect on length of life. The hens in this experiment have served as a foundation stock for a low-mortality line. Breeding hens have been selected showing no mortality in their families for three generations.

\section{Interval as an Index of Annual Production}

In a four-year study the egg records did not reveal any consistent irregular layers, the pullets generally laying at normal intervals of 24 hours or more within the cycles. Annual egg production can be estimated from short periods with a high degree of accuracy by calculating the average time interval between eggs within cycles. 


\section{Methods of Feeding Grain to Pullets}

The method of hopper feeding grain to laying hens has become popular in recent years because of the saving in labor and the elimination of the human element in poultry feeding. In an experiment involving 50 White Leghorn pullets in each lot, the grain was hopper-fed to one lot and litter-fed to the other. During the ninemonth period the hopper-fed and litter-fed lots averaged to lay 48 percent and 42 percent respectively. The pullets consumed 5.2 pounds of feed to produce a dozen eggs in the hopper-fed lot and 5.7 pounds in the litter-fed lot.

\section{Poultry Management}

The work of keeping cost records with poultry producers in recent years indicates that egg production continued to be profitable on those flocks that were managed efficiently. High egg production was necessary to maintain incomes. Some of the flocks that had special markets for their eggs where able to show excellent profits. This would indicate that efficient marketing as well as efficient management of flocks is essential to maintain profitable flocks.

\section{DAIRY SCIENCE}

\section{Simplified Rations for Dairy Cattle}

Dairying is one of the mainstays of West Virginia's agriculture, returning to the producers some $\$ 15,000,000$ annually. To bring about economical means of feeding the dairy cow, experiments have long been undertaken looking toward the lowering of production costs. One of these involves the use of home grown feeds, thereby obviating the necessity for purchasing high-priced concentrates.

One group of purebred heifers of the various breeds received a ration of alfalfa hay and yellow cornmeal, while another group was fed a like ration plus corn silage. Both groups received pasture in season. The rations were studied for their effects on growth, production, reproduction, and lactation.

Ten animals on the alfalfa-cornmeal ration have made normal growth and have given birth to living calves, and there is every indication that this ration is adequate for normal growth and reproduction. Five of the animals on the alfalfa-cornmeal ration received corn silage after the beginning of the lactation period. Returns to date indicate that corn silage is of little additional value 


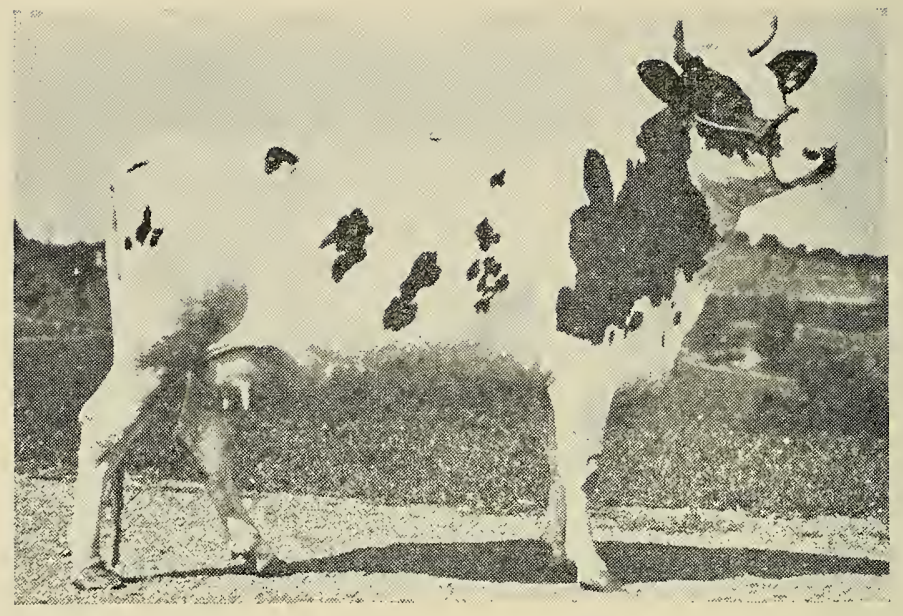

Timothy hay and yellow cormmeal supplemented with corn gluten meal and without pasture made up the ration for this animal, photographed near the end of her first lactation. This ration does not necessarily support normal reproduction

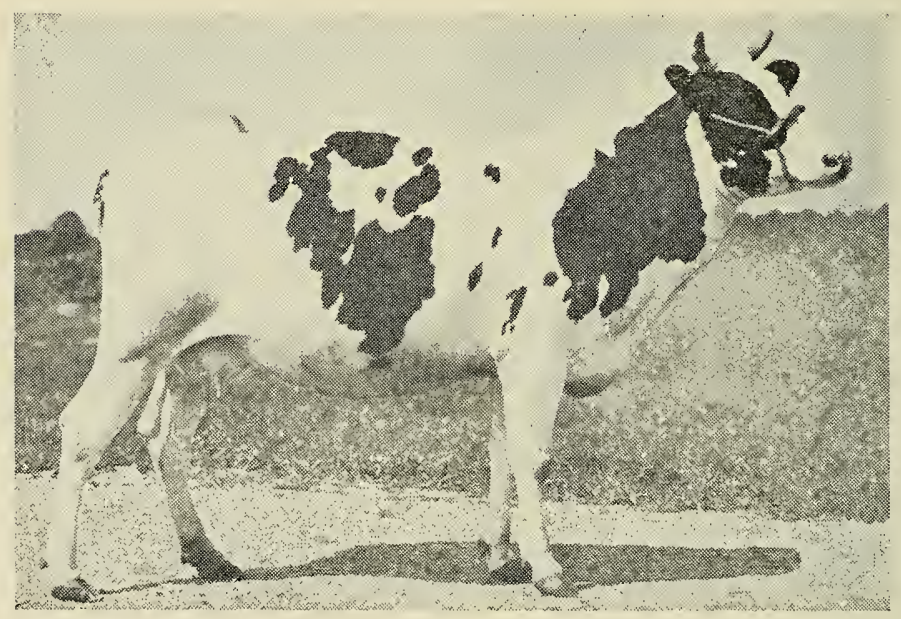

Alfalfa hay and yellow cornmeal without pasture made up the ration for this animal, photographed near the end of her first lactation. Apparently this ration is adequate for normal growth and reproduction 
when included in a well-balanced ration. Mere succulence is of itself belicved to add little feeding valuc, just as, in earlier trials, dry beet pulp was found equal to wet pulp in milk production.

A third group of five heifers was fed timothy hay and yellow cornmeal supplemented with corn-gluten meal. All these made normal growth, but two animals aborted shortly after being turned on pasture. It is possible that the long winter-feeding period on this ration had so depleted the body reserves in certain essentials as to cause the abortions.

\section{Sweet Clover as a Summer Pasture}

Good bluegrass pasture when well cared for will produce more feed than will sweet clover grown under similar conditions. Sweet clover, however, has proved a fairly good supplement to bluegrass as observed in a comparison made at the Reymann Memorial Farms for four pasture seasons. The comparison was made between (1) a permanent bluegrass sod, which contains a considerable amount of white Dutch clover; (2) sweet clover seeded at the rate of 20 pounds per acre with $1 \frac{1}{2}$ bushel of oats; and (3) sweet clover seeded at the rate of 8 pounds per acre with 1 bushel of Canada field peas, 11/2 bushel of oats, and 8 pounds of Sudan grass.

Bluegrass is well known for its long grazing season, but its fault of growing but little during the hot and usually dry months of July and August makes a supplemental pasture for these months generally desired. Sweet clover was found to be fairly valuable as such a supplement, producing during these two months an average of 51 percent of its total pasture days the first year and 35 percent the second year, while bluegrass produced only 28.6 percent of its pasture days during the same period.

The presence of the field peas and Sudan grass did not injure the sweet clover where used. In fact, the advantage seems to lie with the lighter seeding of sweet clover.

\section{Flavor Studies of Milk}

Recent work at this Station has yielded strong evidence that the rich flavor of whole milk, previously attributed to butterfat alone, is enhanced by the phospholipids associated with the fat in milk. These fat-like compounds are largely concentrated at the surfaces of the fat globules but disengage from them to a large extent during churning and are left in the buttermilk. This probably is the principal reason why buttermilk has a richer, more pleasing flavor than 
skimmilk. It would be expected also that ice cream made from butter would fail to have as rich and pleasant a flavor as ice cream of similar composition made from cream, inasmuch as a considerable portion of the phospholipids is eliminated and left in the buttermilk in the first case but is retained in the ice cream in the second.

In recent years much has been done on the subject of oxidized flavor, also variously known as cappy, cardboard, papery, metallic, oily-tallowy, and emery taste. Work at this Station has fully confirmed the contention that iron and copper dissolved in milk of low bacterial content usually will cause the development of this flavor. One of the most important means of controlling the flavor in the milk plant therefore is the complete elimination of copper and iron as contact surfaces for the milk.

\section{Bitter Flavor in Sour Cream}

For several years creamerymen who buy cream produced in West Virginia for buttermaking have pointed out that a large proportion of the cream coming to their plants from West Virginia during the cold months of the year is bitter in flavor. This fact prompted a study of the causes of the bitter flavor.

Careful study of a large number of samples of the bitter cream arriving at centralizer creameries was made. It was found that most of the cases of bitterness were caused either by bacteria or by lipase, an organic substance which causes the breaking down of butterfat into compounds which are bitter.

A careful study of the creamery records showed that those shipments which were bitter generally were old. The development of bitterness due to the causes found in this study is slow, and it is almost a certainty that to avoid the development of bitterness in his cream the producer must not allow his cream to become old before shipping it. Shipping every four days would be ideal for sour cream. In no case should cream be kept at the farm longer than one week during the winter months.

\section{FARM MANAGEMENT}

\section{Land Utitization in the Huntington Area}

The "Huntington area" comprises Wayne, Cabell, and Lincoln counties and those parts of Mason and Putnam counties south of the Kanawha River. A study begun in 1932 has revealed that for the 
crop year 1931-32, out of 391 farms, 163 yielded an average labor income of $\$ 509$, while 228 sliowed a minus labor income of $\$ 258$.

Supervised farm accounts were completed on 130 farms for the crop year 1932-33. Of this number 48 showed a positive labor income, while 82 showed a negative labor income. Out of the total number of 521 farms for which records were obtained during the two years, 353 had incomes from sources other than the farm. While a number of good-sized farms occur in the area, the majority are subsistence and part-time farms.

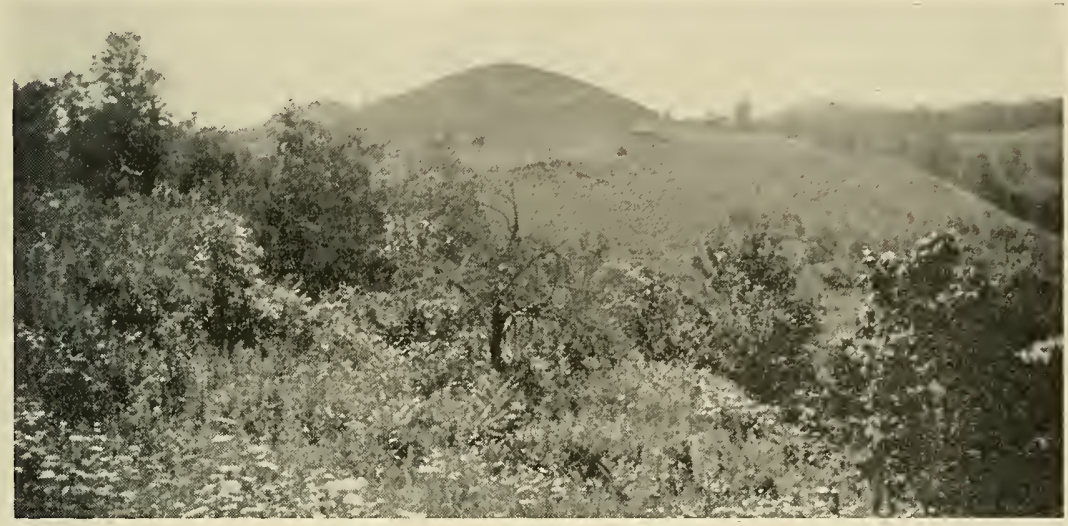

Typical terrain in the Huntington area. Much of the land is too steep for tillage

Maps were made of 96 representative farms in the area. Only 19 percent of the area mapped had a slope of from 7 to 15 degrees; and 73 percent a slope greater than 15 degrees. This would indicate that no more than 27 percent of the land in farms in the area is economically tillable from the standpoint of slope. This tillable land furthermore is by no means proportionally distributed among the farms or the various counties. The small area of tillable land would point to an intensive type of farming, but this is not the case. It was found that only about 37 percent of the farmers used any commercial fertilizer, and most of this was used on the tobacco crop.

There is not sufficient productive land in the area to support the rural population under the present system of management and ownership, and much of the steeper lands needs to return to forest. A more intensive type of agriculture would help the situation since large numbers of farm people depend on outside work for a part of 
their income. A revival of industrial activity would help, but many have depended on work in timber and the oil fields for the major part of their incomes. Both of these industries appear to be on the decline in the area. Unless some new source of income from industry can be brought to the people, it is difficult to see how the present large rural population can be supported from the land.

\section{Use of Power on West Virginia Farms}

Personal visits have been made to about 450 farms in various sections of the state and record of the extent and cost of each type of power on the farm obtained. The types of power covered in this survey were horses, tractors, automobiles, trucks, stationary engines, and electricity.

The average age of 667 horses on non-tractor farms was 11.6 years. Two-thirds of these horses were ten years of age or older. On tractor farms 340 of the 558 horses had passed the age of ten. Few replacements were being raised although there was a noticeable tendency to increase the production of colts. This situation would indicate that there will be a good market for horses for some years to come.

Of the 441 farms visited, 133 used stationary engines, and 148 used electricity. There were auto trucks on 120 and automobiles on 261 of the farms.

There was a marked tendency on the part of tractor owners to use their horses more and the tractors less than ordinarily. They gave as the reason that they had feed for the horses. There was no market for surplus feed crops on hand, whereas fuel for the tractor had to be paid for in cash and most farmers had very limited amounts of cash available or obtainable.

\section{MISCELLANEOUS}

\section{Preserving the Flavor of Nut Meats}

In encouraging home industries the extension agencies of the state have developed a considerable trade in black walnut kernels amounting in some years to sales of ten thousand pounds. One difficulty encountered in the project has to do with keeping the kernels in a sweet, palatable condition over a period of months after their removal from the shells. Under ordinary conditions of storage the meats deteriorate rapidly, particularly in warm weather, and soon 
become rancid and unfit for use. A considerable advantage would be gained if this difficulty could be overcome and a supply of fresh meats made available throughout the year.

Two years ago a beginning was made in which various kinds of storage conditions were tried out, and some progress has been made. One drawback in the study has been the lack of a satisfactory measure of rancidity or incipient rancidity. Different individuals have different tastes, and a product regarded as good by one person may be considered as decidedly off flavor and unacceptable to another. A chemical method for measuring the degree of rancidity is being sought.

\section{Vitamin $A$ and Colds}

Records from 200 University students have been compiled showing the incidence of colds when treated with codliver oil or other rich source of vitamin $\mathrm{A}$, and also when untreated. Results show a reduction of 8 days in duration of colds for the first half year when cod-liver oil, haliver oil, or carotene was taken. Codliver oil seems to reduce colds slightly more than does carotene or haliver oil, which suggests that vitamin $D$ may be a factor as well as vitamin $A$ in resistance to colds. A photometer has been used with some success to measure vitamin A reserve in human subjects.

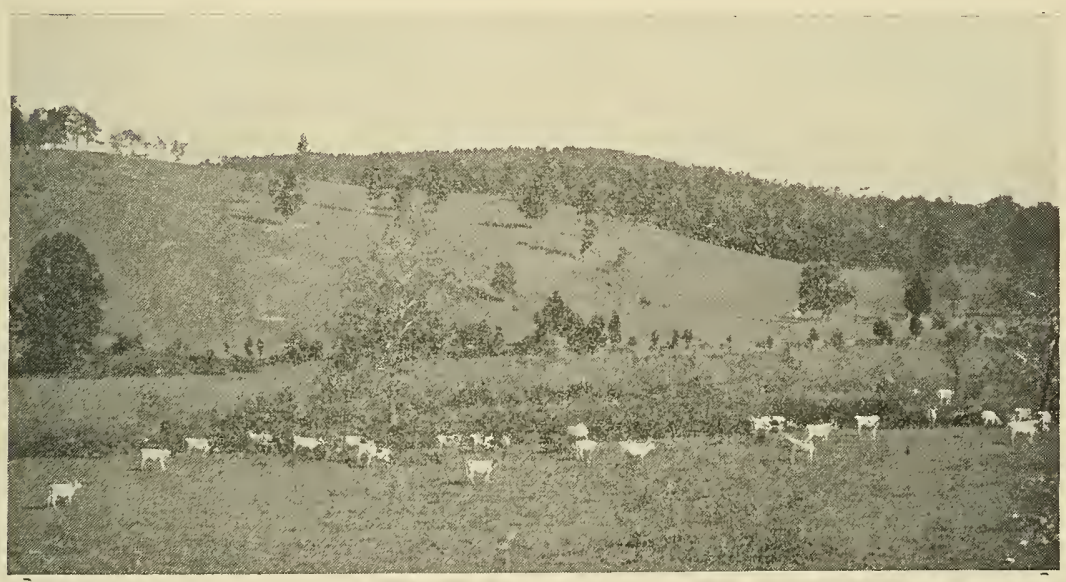

Ayrshires graze in fertile pastures at Reymann Memorial Farms, Wardensville 


\section{Agricultural Experiment Station Staff}

JOHN R. TURNER, Ph. D., LL. D., President of the University

F. D. FROMME, Ph. D. ................... Dean and Director GERALD JENNX, M. S., Agricultural Editor....JOHN C. TOHNSTON, Chief Clerk

\section{AGRONOMY AND GENETICS}

R. J. Garber, Ph. D. Agronomist and Geneticist

W. H. Pierre, Ph. D. Associate Agronomist

T. C. McIlvaine, Ph. D. ${ }^{*} \dagger$ Assistant Agronomist

G. G. Pohlman, Ph. D. Assistant Agronomist

C. R. Burnham, Ph. D. Assistant Geneticist

L. S. Bennett, M. S. Assistant

R. R. Robinson, IM. S. Graduate Assistant

\section{ANIMAL HUSBANDRY}

E. A. Livesay, D. Sc. Animal Husbandman

C. V. Wilson, M. S. Assistant Animal Husbandman

J. H. Longwell, M. A. Assistant Animal Husbandman

R. H. Tuckwiller, B. S. Agr.* Assistant Animal Husbandman

J. H. Rietz, D. V. M. Associate Veterinarian

E. T. Wightman, M. S. Assistant Poultry Husbandman

T. B. Clark, M. S. Assistant in Poultry Research

A. W. Hamilton, B. S. Agr. Graduate Assistant

\section{CHEMISTRY}

R. B. Dustman, Ph. D. Agricultural Chemist

C. E. Weakley, Jr., M. A. Assistant Chemist

A. H. Van Landingham, Ph. D. Assistant Chemist

I. J. Duncan, M. S. Assistant

\section{DAIRY HUSBANDRY}

H. O. Henderson, Ph. D. Dairy Husbandman

L. M. Thurston, Ph. D. Associate Dairy Husbandman

G. A. Bowling, M. S. Assistant Dairy Husbandman
R. A. Ackerman, M. S. $\ddagger$ Assistant Dairy Husbandman

W. C. Brown, M. S. Graduate Assistant

Howard Dickey, B. S. Graduate Assistant

\section{ENTOMOLOGY}

L. M. Peairs, Ph. D. Entomologist

Edwin Gould, B. S. Agr. Assistant

\section{FARM ECONOMICS}

W. W. Armentrout, Ph. D. Farm Economist

F. D. Cornell, Jr., M. S. Assistant Farm Mechanician

R. O. Stelzer, M. S. Assistant Farm Economist

\section{HOME ECONOMICS}

Rachel H. Colwell, M. A. Home Economist

Hazel C. Cameron, M. A. Research Specialist in Nutrition

\section{HORTICULTURE}

H. E. Knowlton, Ph. D. Horticulturist

K. C. Westover, M. S. Assistant Horticulturist

Leif Verner, $\mathrm{Ph}$. D Assistant Horticulturist

E. N. McCubbin, M. A. Assistant

A. P. Dye, M. S. Agr. Assistant

W. H. Childs, M. S. Assistant

\section{PLANT PATHOLOGY}

C. R. Orton, Ph. D. Plant Pathologist

L. H. Leonian. Ph. D. Mycologist

Anthony Berg, M. S. Associate Plant Pathologist

F. J. Schneiderhan, Ph. D. $\dagger$ Associate Plant Pathologist

A. R. Stanley, M. S. Graduate Assistant

W. D. Henry, M. S. Graduate Assistant

*In cooperation with the U. S. Department of Agriculture, Washington, D. C.

In charge of the Lakin Experiment Farm, Lakin, W. Va.

In charge of the Reymann Memorial Farms, Wardensville, W. Va.

tiIn charge of the University Experiment Farm, Kearneysville, W. Va. 


\section{STAFF CHANGES}

Promotions within the research staff during the biennium include W. W. Armentrout, farm economist; L. H. Leonian, mycologist ; R. O. Stelzer, assistant farm economist; A. H. Van Landingham, assistant chemist; and E. T. Wightman, assistant poultry husbandman. New appointments include L. S. Bennett, assistant in agronomy, and C. R. Burnham, assistant geneticist. M. M. Hoover, associate agronomist, resigned during the same period.

\section{PUBLICATIONS OF THE BIENNIUM 1932-34}

\section{BULLETINS AND CIRCULARS}

Bul. 253. Inheritance studies of the reaction of selfed lines of maize to smit (Ustilago zeae). M. M. Hoover. Technical. 32 pages. Nov. 1932.

Bul. 254. Report of the West Virginia Agricultural Experiment Station for the biennium ending June 30, 1932. General. 60 pages. Dec. 1932.

Bul. 255. The bacterial flora of high-grade milk before and after pasteurization.

L. M. Thurston and H. C. Olson. Technical. 24 pages. June 1933.

Bul. 256. Roots as a feed for dairy cattle. H. O. Henderson and K. S. Morrow. General. 16 pages. June 1933. (Out of print.)

Bul. 257. Fusarium niveum, the cause of watermelon wilt. Bailey Sleeth. Technical. 24 pages. Feb. 1934.

Bul. 258. West Virginia birds-a check list. P. C. Bibbee. General. 48 pages. April 1934.

Bul. 259. Control and eradication of Brucella abortus infection in a dairy herd. J. H. Rietz and G. A. Bowling. Technical. 12 pages. May 1934.

Bul. 260. Black pox and other apple-bark diseases commonly known as measles. A. Berg. Technical. 32 pages. June 1934.

Cir. 61. Growing raspberries in West Virginia. H. E. Knowlton and C. R. Orton. 20 pages. March 1933.

Cir. 62. Pollination of fruit trees in West Virginia. H. E. Knowlton. 12 pages. March 1933.

Cir. 63. Potato production in West Virginia. K. C. Westover. 28 pages. May 1933.

Cir. 64. Strawberries for West Virginia farms. W. H. Childs. 16 pages. May 1933.

Cir. 65. Farm or forest in the West Virginia Appalachians A. J. Dadisman. 12 pages. June 1933.

Cir. 66. Vitamins every day. Hazel C. Cameron. 16 pages. Oct. 1933.

Cir. 67. Selection and management of the dairy herd sire. G. A. Bowling. 16 pages. Oct. 1933.

\section{MTMEOGRAPHED CIRCULARS}

No. 4. Variety and strain tests of vegetables at the Lakin Experimental Farm during 1932. K. C. Westover, A. L. Keller, and T. C. McIlvaine. Feb. 1933.

No. 5. Fine-wool sheep summary for the year ending Sept. 30, 1932. R. O. Stelzer. April 1933.

No. 6. Time of picking of Montmorency cherries. Leif Verner. June 1933.

No. 7. West Virginia poultry cost records: Summary for 1932 . R. O. Stelzer. June 1933.

No. 8. The farm housing survey in West Virginia. Gertrude Humphreys and F. D. Cornell, Jr. June 1934.

No. 9. Varietv and strain tests of vegetable crops at the Lakin Experimental Farm during 1933. K. C. Westover, T. C. MeIlvaine, and E. N. MeCubbin. Febr. 1934. 


\section{SCIENTIFIC PAPERS}

No. 104. H. O. Henderson and A. H. VanLandingham. Method for obtaining representative samples of blood for inorganic phosphorus in dairy heifers. Jour. Dairy Sci. 15, 4: 313-319. July 1932.

No. 105. L. M. Thurston and J. L. Barnhart. Some observations on the acid coagulation of skimmilk. Jour. Dairy Sci. 15, 5: 401-405. Sept. 1932.

No. 106. R. B. Dustman. A modified microburette. Ind. and Eng. Chem. 4: 345-347. July 15, 1932.

No. 107. Hazel C. Cameron. Ferrous iodide as a substitute for vitamin A in rats. Science 76 , no. 1957: 18-19. July 1, 1932.

No. 110. M. M. Hoover and M. H. Snyder. Natural crossing in oats at Morgantown, W. Va. Jour. Amer. Soc. Ágron. 24, no. 10: 784-786. Oct. 1932.

No. 111. W. H. Pierre, G. G. Pohlman, and T. C. MeIlvaine. Soluble aluminum studies: I. The concentration of aluminum in the displaced soil solution of naturally acid soils. Soil Seience 34, no. 2: 145-160. Aug. 1932.

No. 112. W. S. Ligon and W. H. Pierre. Soluble aluminum studies: II. Minimum concentrations of aluminum found to be toxic to corn, sorghum, and barley in eulture solutions. Soil Science 34, No. 4: 307-321. Oct. 1932.

No. 113. R. T. Garber and W. H. Pierre. Variation of yields obtained in small artificially constructed field plats. Jour. Amer. Soc. Agron. 25, No. 2: 98-105. Feb. 1933.

No. 114. W. H. Pierre and G. G. Pohlman. Preliminary studies of the exuded plant sap and the relation between the composition of the sap and the soil solution. Jour. Amer. Soc. Agron. 25, No. 2: 144-160. Feb. 1933.

No. 115. G. G. Pohlman and W. II. Pierre. The phosphorus concentration of the exuded sap of corn as a measure of the available phosphorus in the soil. Jour. Amer. Soc. Agron. 25, No. 2: 160-171. Feb. 1933.

No. 116. L. M. Thurston and Ira Gould, Jr. Factors governing the manufacture of sweet-curd cottage cheese. Tour. Dairy Sci. 16, 5: 467-480. Sept. 1933.

No. 117. T. B. Clark. The effect of multiple turning upon the growth of chick embryos. Poult. Sci. 12, no. 5: 279-281. Sept. 1933.

No. 118. H. O. Henderson and C. E. Teague. Wet vs. dry beet pulp for milk production. Jonr. Dairy Sci. 16, no. 4: 363-368. July 1933.

No. 119. G. G. Pohlman. Soluble aluminum studies: III. The relation of nitrification and sulfur oxidation to the aluminmm and hydrogen-ion concentration of some very acid soils. Soil Science 36, no. 1: 47-55. July 1933.

No. 120. F. D. Cornell, Jr. Recent developments in stationary spray systems in West Virginia. Agric. Eng. 14, no. 3: 79-80. March 1933.

No. 121. Hazel C. Cameron. A comparison of the value of ferlous iodide administered directly and indirectly. Soc. for Exp. Biol. and Med. (Proc.) 30: 762-765. 1933 .

No. 122. W. H. Pierre and A. D. Stuart. Soluble aluminum studies: IV. The effects of phosphorus in reducing the detrimental effects of soil acidity on plant growth. Soil Science 36, no. 3: 211-227. Sept. 1933.

No. 123. K. C. Westover. Effect on vigor and yield of storing cut potato sets. Amer. Pot. Jour. 10, no. 11: 209-223. Nov. 1933. -

No. 124. W. I. Childs and M. B. Hoffman. Nitrate fertilization of Latham red raspberries. (Proc.) Amer. Soc. Hort. Sci. 29: 302-305. 1932.

No. 125. E. N. MeCubbin and K. C. Westover. Influence of soil type on results from paper mulch trials with tomatoes. (Proc.) Amer. Soc. Hort. Sci. 29: 458-462. 1932.

No. 126. R. B. Dustman. The effect of ethylene, ethylene chlorohydrin, and ultraviolet light on the carbohydrate content of stored apples. Plant Phys. 9: 637-643. July, 1934.

No. 12S. W. H. Pierre. Determination of eanivalent acidity and basicity of fertilizers. Jour. Ind. and Eng. Chem. 5: 229-243. July 15, 1933.

No. 129. W. H. Pierre. Effect of mono-, di-, and tricalcium phosphate on the reaction of soils of different degrees of acidity. Jour. Amer. Soc. Agron. 26, no. 4: 278-289. April 1934. 
No. 130. I. J. Duncan and R. B. Dustman. Quantitative determination of coumarin in plant material. Jour. Ind. and Eng. Chem. (anal. ed.) 6: 210. May $35,1934$.

No. 131. W. 11. Pierre. The equivalent acidity and basicity of fertilizers as determined by a newly-proposed method. Jour. Asso. Off. Agr. Chemists 17, No. 1: 101-107. Febr. 1934.

\section{OTHER PAPERS PUBLISHED DURING THE BIENNIUM}

W. H. Pierre. A method for determining the acid- or base-forming property of fertilizers and the production of non-acid-forming fertilizers. Ameriean Fertilizeb, Oct. 21, 1933. Also Commereial Fertilizer, Norember, 1933.

L. M. Thurston. Sweet-curd cottage cheese. Milk Dealer, December, 1933.

H. O. Henderson and C. E. Teague. Wet vs. dry beet pulp for mill production. Jersey Bulletin 53, no. 9: 230. August, 1934.

G. A. Bowling. Ten years of progress at Reymann Memorial Farms. Ayrshire Digest 19, no. 11: 7. November, 1933.

C. R. Orton. The virous diseases of plants. Bul. Am. Delphinium Soc. 4: 26-33. 1933.

C. R. Ortoll. Reaction of tissues from individual plants to soft-rot bacteria. Phytopath. 23: 26. 1933 (Abstract).

C. R. Orton and A. R. Stanley. Serum-Agglutination studies with soft-rot bacteria. Phytopath. 23: 27. 1933 (Abstract).

\section{CURRENT PROJECTS}

\section{AGRONOMY AND GENETICS}

Variety testing of corn, wheat, oats, and soy beans (CE 6)

Corn breeding ( $\mathrm{CE} 7$ )

Soil survey work in West Virginia (CE 8)

Cover crop experiments (CE 9; coop. Dairy Husbandry)

Alfalfa investigations (CE 10)

Crop rotation experiments (CE 11)

The availability of phosphorus compounds (CE 12)

Sweet clover investigations (CE 13; coop. Agricultural Chemistry)

Crop responses to various fertilizers (CE 14)

Breeding tobacco for resistance to root rot and high yield (P 1; coop. U. S. D. A.)

Soil acidity and plant growth ( $\mathrm{P}$ 2)

Pasture fertilization studies ( $\mathrm{P} 3$; coop. Dairy Husbandry and U. S. D. A.)

Fusarium wilt of watermelon (P 18; coop. Plant Pathology)

\section{ANIMAL HUSBANDRY}

The effects of rations and methods of feeding grain on egg production (CE 15)

The proper incubating temperature for eggs of the domestic fowl in incubators of the cabinet type (CE 16)

Battery rations for growing chicks (CE 17)
Relation of round-worm (Ascaris lumbricoides) infestation and vitamin-A defieiency in pigs ( $P$ 4)

Breed as a factor in sheep production and quality of products produced ( $\mathrm{P}$ 5 ; coop. U. S. D. A.)

Investigations concerning treatment for stomach and lung worms in sheep and cattle ( $P$ 6)

Herd management for the production of slaughter and feeder calves (P 7; coop. Farm Economies and U. S. D. A.)

Corn silage studies (P 22; coop. Agricultural Chemistry)

Factors affecting the weight of hen's eggs (A 7)

The time factor in egg production (A 8)

\section{BIOLOGY}

Relation of vitamin-A intake to common colds (P 15)

Histology and bone growth in vitamindeficient animals (P 26)

\section{CHEMISTRY (AGRICULTURAL)}

A study of the pigmentation and ripening of fruits (A 3)

Miscellaneous chemical investigations (CE 5)

A study of the variability in composition of different skeletal parts of experimental animals (P 21) 


\section{DAIRY HUSBANDRY}

Cost of raising dairy heifers in W. Va. (CE 20)

A growth study with Ayrshire cattle (CE 21)

A study of the different varieties of pasture for milk production (CE 22; coop. Agronomy)

The water consumption of dairy animals (CE 23)

The effect of low-calcium and low-phosphorus rations on growing dairy heifers (P 8; coop. Agricultural Chemistry)

The transmission of milk and butterfat production and body conformation by dairy sires (P 14; coop. U. S. D. A.)

A study of the causes and methods of prevention of oxidized flavors in milk (P 23)

Causes for poor quality of cream transported in less than car lots ( $\mathrm{P} 24$ )

A comparison of alfalfa and timothy hay with and without corn silage for dairy cattle ( $P$ 25)

\section{ENTOMOLOGY}

Miscellaneous insect and insecticide studies (CE 24)

The biology and control of insects of major importance in commercial orchards in West Virginia (P 9; coop. Maryland, Pennsylvania, Virginia, U. S. D. A.)

Relation of temperature to insect life (A 1)

\section{FARM ECONOMICS}

Deep tillage studies with field, truck, and orchard crops (CE 25; euop. Agronomy and Horticulture)

Poultry as a farm enterprise (CE 26)

A comparison of loan appraisals on real estate with assessments ( $P$ 10)

A study of the Charleston area as a market for truck eru; a nd farm produce (P 12; coop. State Relief Administration)

The economic and social development of families in Roane and Wirt counties as affected by the soil erosion control program (P 13 ; coop. U. S. Department of the Interior)

Cost and efficiency of milk distribution (P 27; coop. Dairy Husbandry)

The cost of milk production (P 28; coop. Dairy Husbandry)

A study of the economic and social progress of homesteaders of the Arthurdale and Tygart's Valley homesteads (P. 29; coop. Rural Organization, and U. S. Department of the Interior)

Types of farming in West Virginia ( $\mathrm{P}$ 20 ; coop. U. S. D. A.)

\section{HORTICULTURE}

Sterility studies with the apple (A 2)

Hardiness studies of the fruit buds of peach (A 4; coop. Agricultural Chemistry)

Miscellaneous horticulture investigations (CE 27)

Cultural treatments and fertilizers for fruits (CE 28)

Variety tests of tree and small fruits (CE 29)

Training and pruning fruit trees (CE 30)

Variety and strain studies of vegetables (CE 31)

Green manure rotations for upbuilding and maintaining soil fertility in vegetable erop production (P 11)

The improvement of fruit-tree root stocks (P 16; coop. U. S. D. A.)

The causes of fruit splitting in the apple ( $P$ 17)

Cooperation with subsistence homesteads in the production of farm and garden products (CE 32 ; coop. all departments and U. S. Dept. of Interior)

\section{PLANT PATHOLOGY}

\section{Apple rust (A 5)}

The effect of environment upon morphology and parasitism in fungi ( $A$ 6)

Apple measles (P 19)

Collar and root diseases of fruit trees (P 21)

Forcst tree diseases (CE 18)

Miscellaneous plant disease investigations (CE 19) 

